\title{
Bireysel ve Davranışsal Faktörlerin Restoran Müşterilerinin Şikâyet Etme Niyetlerine Etkisi
}

The Effects of Behavioral and Individual Factors on Restaurant Customers' Intention to Complain

\author{
Bahattin ÖZDEMIR*, Gökhan YILMAZ ${ }^{* *}$, Osman ÇALIŞKAN ${ }^{* * *}$ \\ *Doç. Dr., Akdeniz Üniversitesi, Turizm Fakültesi Gastronomi ve Mutfak Sanatları Bölümü, 07058, Kampüs, Antalya. \\ E-posta:bahattin@akdeniz.edu.tr \\ ${ }^{* *}$ Arş. Gör., Akdeniz Üniversitesi, Turizm Fakültesi, 07058, Kampüs, Antalya. \\ E-posta: gokhanyilmaz@akdeniz.edu.tr \\ ***Yrd. Doç. Dr., Akdeniz Üniversitesi, Turizm Fakültesi Gastronomi ve Mutfak Sanatları Bölümü, 07058, Kampüs, Antalya. \\ E-posta: ocaliskan@akdeniz.edu.tr
}

\section{MAKALE BILGILERI}

Makale ișlem bilgileri:

Gönderilme tarihi: 20 Mart 2014

Birinci değerlendirme: 12 Mayıs 2014

Kabul: 30 Mayıs 2014

Anahtar sözcükler:

Restoran, Restoran işletmeciliği, Müşteri şikâyet davranışı, Şikâyet etme niyeti.
ÖZ

Bu araștırma bireysel ve davranıșsal faktörlerin restoran müșterilerinin șikâyet etme niyetlerine etkisini incelemeyi amaçlamaktadır. Alanyazın taramasının ardından davranışsal faktörler olarak planlı davranış kuramının temel değişkenleri (tutum, öznel normlar ve algılanan davranışsal kontrol); bireysel faktörler olarak da enformasyon düzeyi ve kendini önemseme inceleme kapsamına alınmıștır. İstanbul'da yapılan çalıșmada 582 kișiye soru formları dağıtılmış; eksik doldurulan ve uç değerler nedeniyle elenen soru formları olmasından dolayı 375 adet soru formu değerlendirmeye alınmıştır. Doğrulayıcı faktör analiziyle ölçüm modelinin uygunluğu belirlendikten sonra araștırma modelinde yer alan beș hipotez yapısal eșitlik modeli ile test edilmiștir. Hipotezlerin tamamı araștırma bulgularından destek bulabilmiștir ve araştırma bulguları tutum, algılanan davranışsal kontrol, öznel normlar, kendini önemseme ve enformasyon düzeyinin restoranlarda müşterilerin şikâyet etmeye ilişkin niyetlerini belirleyen faktörler olduğunu göstermiştir. Çalışma uygulamacılar ve ileriki araştırmalar için öneriler ile sonuçlandırılmıştır.
ARTICLE INFO

Article history:

Submitted: 20 March 2014

Resubmitted: 12 May 2014

Accepted: 30 May 2014

Key words:

Restaurant, Restaurant manage-

ment, Customer Complaint Behavior,

Intention to complain.

\section{ABSTRACT}

This study aims at exploring the effects of behavioral and individual factors on restaurant customers' intentions to complain. Relying on the prior research, the current paper operationalized the variables of planned behavior theory (attitudes, subjective norms, and perceived behavioral control) as behavioral factors whereas information level and self-importance were included into the model as the representatives of individual factors. Questionnaires were administered to 582 participants in i̇stanbul. After elimination of questionnaires which were not completed or contained extreme values, remaining 375 questionnaires were further analyzed. First, a confirmatory factor analysis was conducted to evaluate the measurement model. Second, five hypotheses of the research were tested by using structural equation modeling. The findings supported all the hypotheses. Specifically, the research revealed that attitude, subjective norms, perceived behavioral control, self-importance, and information level were good predictors of restaurant customers' intention to complain. Study concluded with recommendations for practice and future research.

\section{Giriş}

İşletmeciliğin diğer alanlarında olduğu gibi restoran işletmeciliği alanında da müşterilerin memnuniyeti, varlığın sürdürebilmesi ve kârlılığın arttırabilmesi için temel faktör olarak kabul edilmektedir. Dahası, memnun edilmiş müşterilerin sadık müşterilere dönüşme olasılığı da hesaba katıldığında, sadık müşteri tabanını genişletme, restoranların en önemli hedefleri arasına yerleşmektedir. Ana akım alanyazında olduğu gibi restoran hizmetleri bağla- mında yapılan araştırmalarda da müşteri memnuniyeti, daha çok müşterilerin beklentilerinin karş1lanması ile ilişkilendirilmektedir (Kivela vd. 2000; Weiss vd. 2004). Ancak en başarılı işletmeler bile müşterilerinin tüm beklentilerini karşılamakta zorluklar yaşayabilmektedir. Bu sebeple restoranlarda hizmet hataları oluşmakta ve bu hatalar müşteri memnuniyetsizliği veya müşteri şikâyetleri ile sonuçlanabilmektedir.

Günümüzde tüketicilerin önemli bir kısmı keyifli bir yemek deneyimi yaşamak üzere restoranları 
ziyaret etmekte (Johns ve Kivela 2001; Hansen vd. 2005) ve bu ziyaretleri sirasinda servis personeli, restoranın atmosferi ve restorandaki diğer müşteriler ile etkileşimlere girmektedir (Wu ve Liang 2009; Lundberg 2011). Söz konusu etkileşimler, restoran müşterilerinin yemek deneyiminden memnun kalmalarını sağlayacak çok önemli etkenler olduğu (Kivela vd. 2000; Antun vd. 2010) gibi yaşanacak olumsuzluklara bağlı olarak memnuniyetsizliğe yol açabilecek birer hata kaynağ da (Susskind ve Viccari 2011) olabilmektedir. Aslında tüketicilerin hizmet sunumunun bir parçası olduğu ve hata yapılma olasılığının da yüksek olduğu ağırlama hizmetlerinde, hataların ve bu hataların yol açabileceği müşteri şikâyetlerinin bütünüyle ortadan kaldırılması olanaksız görünmektedir (Ekiz 2009). Yine de ilgili alanyazındaki araştırmaların bulgula$\mathrm{r} 1$, restoran işletmelerinin hizmet hatalarına uygun hizmet telafileri ile yanıt vermesinin müşteri memnuniyetini (Susskind 2005), müşterinin restorana yeniden gelmesini (Leong ve Kim 2002; Silber vd. 2009; Chua vd. 2010) ve çevresine restoran hakkında olumlu düşüncelerini söylemesini sağlayan (Ok vd. 2006; Kim vd. 2010) önemli bir faktör olduğunu ortaya koymaktadır. Bu durumda, restoran yöneticilerinin müşteriler tarafından şikâyet yoluyla iletilen hizmet hataları ile ilgili geri bildirimleri birer fırsat olarak görmeleri gerektiği önerilmektedir (Karatepe 2006). Bunun için restoranlarda müşterilerin maruz kaldığı hizmet hatalarının neler oldu$\breve{g u}$, bu hataların oluşması durumunda nasıl telafi edileceği, hatalara ve bu hatalar için kendilerine sunulan telafilere müşterilerin nasıl yanıt verdiği, üzerinde düşünülmesi gereken konuların başında gelmektedir. Bu bağlamda araştırmacıların üzerinde durduğu bir diğer önemli konu ise hatalara karşı müşterilerin şikâyet davranışlarıdır.

Restoranlarda müşteri şikâyetleri konusu ile yakından ilgilenen araştırmacılar restoran müşterilerinin şikâyet davranışlarını sınıflandırmış (Lam ve Tang 2003; DeFranco vd. 2005; Kim ve Lynn 2007) ve bu davranışların belirleyicilerini saptamaya çalışmıştır (Velazquez vd. 2006; Mattila ve Ro 2008; Wei vd. 2012). Bu çalışmaların işaret ettiği kritik noktalardan biri restoran müşterilerinin önemli bir kısmının memnuniyetsizliğe neden olan bir hataya maruz kalsa dahi şikâyetini doğrudan restoran yönetimine bildirmemesidir (Wildes ve Seo 2001; Heung ve Lam 2003). Böylece restoran yöneticileri çok önemli bir geri bildirimden ve hataları düzeltme ya da önleme fırsatından yoksun kalmaktadır. $\mathrm{Bu}$ nedenle restoran müşterilerinin şikâyetlerini doğrudan yönetime iletme niyetlerini güçlendiren faktörlerin tespiti büyük önem taşımaktadır. Yabancı alanyazında restoranlarda müşteri şikâyet davranışı ya da niyetini etkileyen faktörler üzerine çok sayıda çalışmanın bulunması da konunun öneminden kaynaklanmaktadır. Türkiye bağlamında ise restoran müşterilerinin şikâyet davranışları ile ilgili sınırlı sayıda çalışma bulunmaktadır. Söz gelimi, Kitapçı (2008) restoran müşterilerinin şikâyet davranış türleri üzerine odaklanmış ve Sivas ilindeki üç restoranda gerçekleştirdiği araştırmada en sık görülen şikâyet davranışının olumsuz deneyimlerin dostlara ve aile bireylerine anlatılması olduğunu saptamıştır. Emir (2011) ise Antalya'daki otellerin restoranlarında gerçekleştirdiği bir araştırmada milliyet ile müşteri şikâyet davranışı arasındaki ilişkiyi incelemiş ve farklı ülkelerden (Türkiye, Rusya, Hollanda ve Almanya) gelen misafirlerin şikâyet davranışlarının da farklı olduğu sonucuna varmıştır. Çalışkan (2013) tarafından yapılan bir araştırmada daha çok restoranlarda hizmet hataları ve telafileri konusuna odaklanılmış ve restoranın hizmet hatasına karşılık uygun bir telafi stratejisi ile yanıt vermesi durumunda müşteri memnuniyetinin de olumlu yönde etkilendiği saptanmıştır. Ancak bu çalışmalarda restoran müşterilerinin şikâyet etme niyetleri ya da eğilimlerini belirleyen faktörler üzerine odaklanılmamış olduğu görülmektedir.

$\mathrm{Bu}$ çalışmada, restoran müşterilerinin şikâyetlerini doğrudan ilgililere iletmelerinin restoran işletmelerinin şikâyete yol açan hatayı tespit etmesine ve ileride tekrar oluşmasını önlemesine yardımcı olacağı, şikâyetçi olan müşteriye sunulacak uygun bir telafi ile müşterinin memnuniyetsizliğinin giderilebileceği ve işletme için etrafına olumlu enformasyon yaymasının sağlanabileceği olgularından hareketle restoranlarda müşteri şikâyetlerini etkileyen faktörler incelenmektedir. Daha açık bir ifade ile bu çalışmanın amacı, ulusal alanyazında pek ele alınmayan bir konu olan bireysel (enformasyon düzeyi ve kendini önemseme) ve davranışsal (tutum, öznel normlar ve algılanan davranışsal kontrol) faktörlerin restoran müşterilerinin şikâyet etme niyetleri üzerindeki etkisini araştırmaktır. 


\section{ALANYAZIN TARAMASI VE MODEL}

Restoranlarda müşteri şikâyetleri ile ilgili görgül araştırmaların özellikle iki ana konu üzerine odaklandığını söylemek mümkündür. Bunlar müşterilerin şikâyet davranışlarının sınıflandırılması (Wildes ve Seo 2001; Gursoy vd. 2003; Mattila ve Ro 2008; McQuilken ve Robertson 2011) ve müşteri şikâyet davranışlarının belirleyicilerinin saptanmaS1 (Su ve Bowen 2001; Jones vd. 2002; Velazquez vd. 2006; Cheng ve Lam 2008; Kim ve Chen 2010; Kim ve Boo 2011; Wei vd. 2012) konularıdır.

\section{Restoranlar Bağlamında Müşteri Şikâyet Davranışlarının Sınıflandırılması}

Araştırmacılar, restoranlar bağlamında müşteri şikâyet davranışlarını sınıflandırırken ana akım alanyazından özellikle Hirschman (1970), Day ve Landon (1977) ve Singh (1988) gibi araştırmacıların önerdiği sınıflandırmaları kuramsal çerçeve olarak ele almışlardır. Kuramsal temellerini bu çalışmalardan alan ve görgül araştırma bulguları ile restoranlar bağlamında müşteri şikâyetlerini sınıfland1ran çalışmalara örnekler Tablo 1'de sunulmaktadır. Bu çalışmalardan biri Lam ve Tang'ın (2003) araştırmasıdır. Bu araştırma ile restoran müşterilerinin şikâyet davranışlarının kişisel eylem (tekrar gelmeme); ağızdan ağıza olumsuz iletişim, yönetime şikâyet ve üçüncü taraflara iletme şeklinde dört grupta incelenebileceği ortaya konulmaktadır. Daha sonra farklı örneklemlerde, DeFranco vd. (2005); Sujithamrak ve Lam (2005) ve Kim ve Lynn (2007) tarafından gerçekleştirilen araştırmaların bulguları da büyük oranda bu sınıflandırmayı desteklemiştir. Daha yakın zamanda Mattila ve Ro (2008) ve Kim vd. (2010) tarafından yapılan çalışmalarda, Rogers vd.'nin (1992) önerisine uyularak eylemsizliğin de restoran müşterilerinin şikâyet davranışlarından biri olarak dikkate alınması gerektiği belirtilmektedir. Böylece restoran işletmeciliği ile ilgili alanyazında dillendirme (şikâyet konusunun doğrudan restoran yönetimine ya da garsona iletilmesi); ağızdan ağıza olumsuz iletişim (tanıdıklara ve diğer insanlara olumsuz deneyimleri aktarma); çıkış (restorana tekrar gelmeme); üçüncü taraflara iletme (zararın tazmini için medya ve yasal organlar gibi kurumlara şikâyeti iletme) ve eylemsizlik (hiçbir şey yapmama) şeklinde beş tür müşteri şikâyet davranışı olabileceği görülmektedir.

Alanyazında sıralanan müşteri şikâyet davranışları arasında dillendirme, şikâyetin doğrudan restoran işletmesine aktarılmasına olanak vermesi açısından üzerinde önemle durulan bir davranış türü olarak öne çıkmaktadır. Restoranlar bağlamında yapılan araştırmalar müşterilerin çok önemli bir kısmının şikâyetini doğrudan restoran yöneticisi ya da garsona iletmediğini ortaya koymaktadır (Wildes ve Seo 2001; Heung ve Lam 2003; Gursoy vd. 2003). Yakın dönemdeki bir araştırmada Wei vd. (2012) cevaplayıcıların şikâyetlerini dillendirmekten çok ağızdan ağıza olumsuz iletişimi tercih etme eğiliminde olduklarını saptamıştır. Yine araştırmalar göstermiştir ki şikâyetini doğrudan restoran yönetimine iletmeyen yani dillendirmeyen müşteriler sadece eylemsiz kalmamaktadır (Gursoy vd. 2003). Çünkü müşteriler birden fazla şikâyet davranışını bir arada sergileyebilmekte (Kim ve Lynn 2007; Kim vd. 2010) ve şikâyetlerini dillendirmedikleri halde olumsuz deneyimlerini ağızdan ağıa iletişim yolu ile tanıdıklarına; zararlarının tazmini ya da yaşadıkları hayal kırıklığını hafifletmek için üçüncü taraflara iletebilmektedir (Lam ve Tang 2003; Kim ve Chen 2010).

\section{Restoranlarda Müşteri Şikâyet Davranışlarının Belirleyicileri}

Alanyazında restoranlarda müşteri şikâyetlerinin açıklanmasında kuramsal altyapılar olarak eşitlik ve adalet kuramları (Lam ve Tang 2003; Kim vd. 2010); öğrenme kuramları (öğrenilmiş çaresizlik) ve maliyet-fayda değerlendirmesi (Gursoy vd. 2003; Mattila ve Ro 2008) gibi yaklaşımlar kullanılmıştır. Böylece alanyazında restoranlarda müşterilerin şikâyet eğilimlerini etkileyen değişkenlerin belirlenmesi veya farklı şikâyet davranışlarından hangisini seçeceklerini belirleyen faktörlerin saptanmasında önemli bir yol alınmıştır. Tablo 2'de bu doğrultuda yapılan araştırmaların örneklerine yer verilmiştir. Bu araştırmaların bulgularının da gösterdiği gibi müşterinin maruz kaldığı hatanın şiddeti (McQuilken ve Robertson 2011) ve memnuniyetsizliği yüksekse (Velazquez vd. 2006); şikâyet ederek bir çözüm elde edebileceğine inanıyorsa (Su ve Bowen 2001; Velazquez vd. 2010); nereye ve nasıl şikâyet edileceği konusunda deneyim sahibiyse (Cheng vd. 2005; Kim ve Boo, 2011); müşteri restoranda yediği yemeği önemsiyorsa (Velazquez vd. 2006; Chang vd. 2012); servis sürecine katılım düzeyi yüksekse (Kim ve Chen 2010) ve maruz kald1ğı hata olumsuz duygular yaşamasına yol açmışsa 
Tablo 1. Restoranlarda Şikâyet Davranışlarının Sınıflandırılması

\begin{tabular}{ll}
\hline Çalışma & Sınıflandırma \\
\hline Wildes ve Seo (2001) & Sözlü bildirme, yazılı bildirme, tekrar gelmeme \\
\hline Heung ve Lam (2003) & $\begin{array}{l}\text { Aile ve arkadaşları uyarma, restorana gelmeyi bırakma, üst kademelere şikâyet } \\
\text { etme, yorum kartı yazma, şikâyet mektubu yazma, medyaya bildirme, tüketici } \\
\text { konseyine şikâyet etme }\end{array}$ \\
\hline Lam ve Tang (2003) & Kişisel eylem (tekrar gelmeme; tanıdıkları uyarma), ağızdan ağıza olumsuz \\
DeFranco vd. (2005) & iletişim, yönetime şikâyet, genele ilan etme (üçüncü taraflara şikâyeti bildirme) \\
\hline Sujithamrak ve Lam (2005) & Kişisel eylem, genele ilan etme (üçüncü taraflara şikâyet), yönetime şikâyet \\
\hline Velazquez vd. (2006) & Şikâyet eylemi (şikâyeti yönetime ve restorana bildirme), özel eylem (tekrar \\
\hline gim ve Lynn (2007) & Üçüncü taraflara iletme (medya, tüketici konseyi ya da otoritelere iletme) özel \\
& eylem (ağızdan ağıza olumsuz iletişim, tekrar gelmeme), dillendirme (garsona \\
\hline ya da yönetime şikâyet)
\end{tabular}

(Mattila ve Ro 2008) şikâyetini dillendirme eğilimi yüksek olabilmektedir. Diğer taraftan müşterilerin cinsiyeti, yaşı, eğitim ve gelir düzeyleri de (Gursoy vd. 2003; DeFranco vd. 2005; Kim ve Boo 2011) şikâyet eğilimlerini etkileyebilmektedir.

İlgili alanyazında Planlı Davranış Kuramı da (PDK) restoranlarda müşteri şikâyetleri bağlamında yararlanılan bir diğer kuramsal yaklaşımdır. Özellikle tüketici davranışlarının anlaşılmasında başarı ile uygulanan bir kuram olan PDK, Cheng vd. (2005) ile Cheng ve Lam'ın (2008) araştırmalarında kullanılmış ve kuramın restoran müşterilerinin şikâyet davranışlarının belirleyicilerini tespit etmede yararlı bir yaklaşım olabileceğine dair ilk işaretler alınmıştır. PDK çerçevesinde şikâyete ilişkin niyet, restoran müşterilerinin şikâyet davranışlarının temel belirleyicisi olarak görülmekte ve niyeti güçlendiren faktörler de davranışa ilişkin tutum, öznel normlar ve algılanan davranışsal kontrol şeklinde sıralanmaktadır.

\section{Araştırma Modeli ve Hipotezleri}

İlgili alanyazının sunmuş olduğu görgül bulgulardan anlaşılacağı üzere restoran müşteri- lerinin şikâyetlerini doğrudan ilgililere iletme oranı oldukça düşük düzeyde kalabilmektedir. Şikâyetlerini dillendirmeyen müşteriler aslında restoran işletmesinin hatasını görmesine yardımcı olacak geri bildirimi işletmeden esirgemiş olmaktadır. Geri bildirimden yoksun kalan restoran işletmesi hatanın telafisi ya da gelecekte tekrarının önlenmesi için herhangi bir önlem alamamaktadır. Üstelik şikâyetini dillendirmeden restorandan ayrilan müşteriler, restorana tekrar gelmeyerek ya da etraflarına restoranla ilgili olumsuz enformasyon yayarak işletmenin mevcut ve potansiyel müşterilerinin kaybında önemli bir rol oynayabilmektedir. Ayrıca restoranlarda müşterilerin şikâyetlerini doğrudan yönetime ya da garsona ileterek dillendirmeleri, restoran yönetiminin şikâyete yol açan hatayı telafi etmesi için de bir gerekliliktir. Ancak bu yolla şikâyetçi olan müşteriye sunulacak uygun bir telafi ile müşterinin memnuniyetsizliği giderilebilmektedir. Bu nedenle, restoran müşterilerinin şikâyetlerini dillendirmelerine etki eden faktörlerin bilinmesi büyük bir önem arz etmektedir. Bu doğrultuda bu çalışmada da restoran müşterileri- 
Tablo 2. Restoranlarda Müşterilerin Şikâyet Davranışını ve Niyetini Etkileyen Faktörler

\begin{tabular}{|c|c|c|}
\hline Çalışma & Bağımsız Değişkenler & Bağımlı Değişken \\
\hline Su ve Bowen (2001) & $\begin{array}{l}\text { Müşterilerin üzgün olma düzeyi } \\
\text { Dışarıda yemek yemenin önemi } \\
\text { Çözüm elde edileceğine ilişkin } \\
\text { algılanan güven }\end{array}$ & Şikâyet etme motivasyonu \\
\hline Jones vd. (2002) & $\begin{array}{l}\text { Sosyo-demografik faktörler } \\
\text { Fiyat bilinci } \\
\text { Psikolojik baskı } \\
\text { Başkalarının etkisinde kalma }\end{array}$ & $\begin{array}{l}\text { Şikâyet davranışlarına göre müşteri grupları (şikâyet etme } \\
\text { olasılığı düşük olanlar; herhangi birine şikâyet edenler, } \\
\text { ağızdan ağıza olumsuz iletişime başvuranlar) }\end{array}$ \\
\hline Gursoy vd. (2003) & Sosyo-demografik faktörler & $\begin{array}{l}\text { Şikâyet davranışlarına göre müşteri grupları (konuşanlar; } \\
\text { dillendirenler) }\end{array}$ \\
\hline Heung ve Lam (2003) & Sosyo-demografik faktörler & $\begin{array}{l}\text { Şikâyet davranışlarına göre müşteri grupları (şikâyet edenler, } \\
\text { şikâyet etmeyenler) }\end{array}$ \\
\hline Lam ve Tang (2003) & Sosyo-demografik faktörler & $\begin{array}{l}\text { Müşterilerin şikâyet davranışı türü (kişisel eylem, ağızdan ağıza } \\
\text { olumsuz iletişim, yönetime şikâyet, üçüncü taraflara şikâyet) }\end{array}$ \\
\hline Cheng vd. (2005) & $\begin{array}{l}\text { Şikâyete ilişkin tutum } \\
\text { Öznel normlar } \\
\text { Algılanan davranışsal kontrol } \\
\text { Şikâyet deneyimi }\end{array}$ & Şikâyet etme niyeti \\
\hline DeFranco vd. (2005) & Milliyet & $\begin{array}{l}\text { Müşterilerin şikâyet davranışı türü (kişisel eylem; ağızdan } \\
\text { ağıza olumsuz iletişim, yönetime şikâyet, üçüncü taraflara } \\
\text { şikâyet) }\end{array}$ \\
\hline Sujithamrak ve Lam (2005) & Demografik faktörler & $\begin{array}{l}\text { Müşterilerin şikâyet davranışı türü (kişisel eylem, üçüncü } \\
\text { taraflara bildirme, yönetime şikâyet) }\end{array}$ \\
\hline Velazquez vd. (2006) & $\begin{array}{l}\text { Memnuniyetsizlik düzeyi } \\
\text { Şikâyete ilişkin tutum } \\
\text { Şikâyetin başarı ile sonuçlanma } \\
\text { olasılığı } \\
\text { Dışarıda yemek yemenin önemi }\end{array}$ & Müşterilerin şikâyet davranışı türü (şikâyet eylemi, özel eylem) \\
\hline Cheng ve Lam (2008) & $\begin{array}{l}\text { Öznel normlar } \\
\text { Algılanan davranışsal kontrol } \\
\text { Alıcı-satıcı arasındaki ilişkinin } \\
\text { düzeyi }\end{array}$ & Şikâyet etme niyeti \\
\hline Mattila ve Ro (2008) & $\begin{array}{l}\text { Olumsuz duygular (kızgınlık, } \\
\text { hayal kırıklığı ve pişmanlık, } \\
\text { üzüntü) }\end{array}$ & $\begin{array}{l}\text { Müşteri şikâyet davranışı türü (doğrudan şikâyet, ağızdan } \\
\text { ağıza olumsuz iletişim, değiştirme, eylemsizlik) }\end{array}$ \\
\hline Kim ve Chen (2010) & $\begin{array}{l}\text { Şikâyet etmenin kolaylığı ve } \\
\text { beklenen fayda } \\
\text { Şikâyete ilişkin tutumlar } \\
\text { Müşteri katılımı } \\
\text { Kendini önemseme }\end{array}$ & $\begin{array}{l}\text { Müşteri şikâyet davranışı türü (dillendirme, çıkış, ağızdan ağıza } \\
\text { olumsuz iletişim, üçüncü taraflara iletme) }\end{array}$ \\
\hline Velazquez vd. (2010) & $\begin{array}{l}\text { Şikâyete ilişkin tutum } \\
\text { Enformasyon düzeyi } \\
\text { Tatminsizlik düzeyi } \\
\text { Şikâyetin başarı ile sonuçlanma } \\
\text { olasılığı } \\
\text { Ürün ve hizmetin önemi }\end{array}$ & Şikâyet etme niyeti \\
\hline Kim ve Boo (2011) & $\begin{array}{l}\text { Şikâyete ilişkin tutum } \\
\text { Şikâyet deneyimi } \\
\text { Yiyeceğin değeri } \\
\text { Harcama miktarı } \\
\text { Mevsim (yaz ya da kış olması) } \\
\text { Demografik faktörler }\end{array}$ & Şikâyet etme niyeti \\
\hline
\end{tabular}


Bireysel ve Davranışsal Faktörlerin Restoran Müşterilerinin Şikâyet Etme Niyetlerine Etkisi

Tablo 2. Restoranlarda Müşterilerin Şikâyet Davranışını ve Niyetini Etkileyen Faktörler (Devamı)

\begin{tabular}{lll}
\hline Çalışma & Bağımsız Değişkenler & Bağımlı Değişken \\
\hline $\begin{array}{l}\text { McQuilken ve } \\
\text { Robertson (2011) }\end{array}$ & $\begin{array}{l}\text { Hizmet garantisi } \\
\text { Hatanın şiddeti } \\
\text { Müşterilerin şikâyetçi olması } \\
\text { için aktif talepte bulunma }\end{array}$ & $\begin{array}{l}\text { Müşteri şikâyet davranışı türü (çıkış, ağızdan ağıza olumsuz } \\
\text { iletşim, dillendirme) }\end{array}$ \\
\hline Wei vd. (2012) & $\begin{array}{l}\text { Benlik kurgusu } \\
\text { Diğer insanlarla birlikte } \\
\text { yemek tüketimi }\end{array}$ & $\begin{array}{l}\text { Müşteri şikâyet davranışı türü (dillendirme, ağızdan } \\
\text { ağıza olumsuz iletişim, değiştirme) }\end{array}$ \\
\hline Chang vd. (2012) & $\begin{array}{l}\text { Hizmet hatası türü } \\
\text { Dışarıda yemek yeme özel } \\
\text { olayı }\end{array}$ & $\begin{array}{l}\text { Müşteri şikâyet davranışı türü (çekinmeden konuşma ve } \\
\text { diğerlerine şikâyet, yönetime şikâyet, pasif yanıt) }\end{array}$ \\
\hline
\end{tabular}

nin şikâyetlerini doğrudan yönetime iletme ya da dillendirme niyetleri üzerine odaklanılmaktadır.

Tablo 2'den restoranlarda müşterilerin şikâyet etme niyetini ya da eğilimini etkileyebilecek çok sayıda faktör olduğu anlaşılmaktadır. Bu faktörleri durumsal faktörler ile bireysel ve davranışsal faktörler şeklinde iki ana grupta incelemek olanaklıdır. Esasen benzer bir ayrım daha önce Kim ve Chen (2010) ile Chang vd. (2012) çalışmalarında da yapılmaktadır. Söz gelimi, Kim ve Chen'in (2010) ayrımına göre müşterinin katılımı, şikâyet etme kolaylığı ve şikâyetten beklenen fayda durumsal faktörler arasında sayılmaktadır. Kendini önemseme ve şikâyete ilişkin tutum ise bireysel ve davranışsal faktörler olarak kabul edilmektedir. Benzer bir anlayışla, bu çalışmada da durumsal faktörlerin memnuniyetsizlik, dışarıda yemek yemenin önemi, şikâyetin başarı ile sonuçlanma olasılığı, olumsuz duygular, hizmet sağlayıcı ile geçmişteki ilişkiler, şikâyet etmenin kolaylığı, hizmet garantisinin sağlanması, hatanın şiddeti ve türü, hatayı başkasına yükleme şeklinde sıralanabileceği söylenebilir. Bu bağlamda durumsal olan faktörlerin en önemli özelliği, etkilerinin bir şikâyet durumundan diğerine farklılık gösterecek nitelikte olmasıdır. Diğer tarafta, bireysel ve davranışsal faktörler ise durumdan bağımsız olarak restoran müşterilerinin şikâyet etme eğilimlerini etkileyebilmektedir. Bu faktörler şikâyete ilişkin tutum, öznel normlar, algılanan davranışsal kontrol, enformasyon düzeyi, sosyo-demografik değişkenler ve kişilik özellikleri olarak sıralanabilmekte ve bunlardan ilk üçü (tutum, öznel normlar ve algılanan davranışsal kontrol) PDK çerçevesinde bireylerin davranışsal niyetlerini belirleyen faktörler olarak kabul edilmektedir.
Faktörleri durumsal ile bireysel ve davranışsal şeklinde bir ayrıma tabi tutmanın birinci nedeni, bu iki grup faktörün şikâyet niyeti üzerinde farklı etkileri olabileceği düşüncesidir. Durumsal faktörler şikâyet durumunun özelliklerinden etkilenmekte ve müşterinin duruma ilişkin anlık değerlendirmesine göre şikâyet eğiliminin ortaya çıkmasına neden olabilmektedir. Bir örnek ile açıklamak gerekirse McQuilken ve Robertson (2011) tarafından da tespit edildiği gibi hatanın şiddeti, şikâyet etme niyetini etkileyebilecek durumsal bir faktördür. Bir başka anlatımla müşterinin bir restoranda şikâyet etme davranışı, maruz kaldığı hatanın şiddetine ilişkin algılamasına göre farklılık gösterebilmektedir (Susskind ve Viccari 2011). Restoranlarda hizmet hatalarını inceleyen araştırmaların bulguları dikkate alındığında yavaş servis, tükenmiş yemek, yanlış pişirme derecesi, uygun olmayan çalışan davranışı, yanlış sipariş, hesap hatası ve yiyecek ve içeceğin dökülmesi (Silber vd. 2009) gibi çok sayıda ve farklı şekillerde hatalar ortaya çıkabilmekte ve müşterilerin hatanın şiddetine ilişkin algılamaları maruz kaldıkları hata türüne göre değişebilmektedir (Chang vd. 2012). Bireysel ve davranışsal faktörler ise her şikâyet durumunun kendisine özgü niteliklerinden bağımsız olarak müşterilerin genel şikâyet eğilimlerini belirleyebilecek türdeki faktörlerdir. Söz gelimi, sosyo-demografik değişkenlerden biri olan milliyet, şikâyet davranışının belirleyicisi olabilmektedir (DeFranco vd. 2005; Emir 2011). Müşterinin milliyeti şikâyet durumuna göre farklılık göstermemekte ancak müşterinin genel şikâyet eğilimi üzerinde etkili olmaktadır. Durumsal faktörler ile bireysel ve davranışsal faktörler ayrımının ikinci nedeni ise bu iki grup faktöre 
ilişkin yapılacak ölçümlerde farklılık olması ve bu farklılık nedeniyle bu faktörleri tek bir araştırmada birlikte ele almanın güçlügüüür. Buna göre durumsal faktörlerin ölçümü daha çok deneysel araştırma tasarımı kapsamında senaryolar kullanmayı gerektirmektedir. Bireysel ve davranışsal faktörler ise geliştirilmiş olan ölçekler yardımıyla ölçülebilmektedir. Söz gelimi, McQuilken ve Robertson (2011) hatanın şiddetine ilişkin ölçümlerinde cevaplayıcilara senaryolar sunmakta ve bu senaryolara göre görüşlerini almaktadır. Böylelikle değiş̧kenin (hatanın şiddetine ilişkin algılama) doğasında yer alan durumsallık ölçüme de yansıtılmıştır. Kim ve Chen (2010) ise bireysel faktörler arasında saydıkları kendini önemseme ve şikâyete ilişkin tutumu iki ayrı ölçek ile ölçmüşlerdir.

Şikâyet etme niyeti kavramına açılılı getiren önemli bir kuram olan PDK, bu çalışmanın da kuramsal dayanaklarından biridir. Gerekçeli Eylem Kuramı'nın (Ajzen ve Fishbein 1970) geliştirilmiş şekli olarak bilinen Planlı Davranış Kuramı (Ajzen 1991), bireylerin bir davranışı sergilemesinde belirleyici olan faktörün söz konusu davranışa ilişkin niyet olduğunu ileri sürmektedir. Buradaki davranışsal niyet kavramı, belirli bir davranışla meşgul olma konusunda bireyin sahip olduğu motivasyon (Lodorfos ve Dennis 2008) olarak tanımlanmaktadır. Şu halde niyet, bireyin bir davranışı sergilemek üzere ne kadar çaba sarf edeceğinin bir göstergesidir (O'Fallon vd. 2007). Bu tanımların ve kuramın işaret ettiği gibi bireylerin belirli bir davranışı sergileme olasılıkları davranışsal niyetlerinin gücü oranında artmaktadır. Yine kurama göre niyetin üç temel belirleyicisi davranışa ilişkin tutum, öznel normlar ve algılanan davranışsal kontrol olarak sıralanmaktadır. Bu çalışmada da restoranlarda müşterilerin doğrudan yönetime ya da görevlilere şikâyet etme eğilimleri PDK çerçevesinde müşterilerin şikâyet etme niyeti olarak kavramsallaşt1rılmakta ve PDK'nın ana değişkenleri olan tutum, öznel normlar ve algılanan davranıssal kontrolün yanı sıra diğer durumsal olmayan değişkenlerden enformasyon düzeyi ve kişilik özelliklerinin müşterilerin şikâyet etme niyeti üzerindeki etkileri incelenmektedir.

PDK'ya göre bireyin davranışa ilişkin tutumu, onun söz konusu davranışla ilgili inanışları ile davranışın sonuçlarına ilişkin değerlendirmelerinden oluşmaktadır. Birey bir davranışa ilişkin olumlu bir tutuma sahipse o davranışı gerçekleştirmeye ilişkin niyeti de güçlenmektedir. Şu halde, müşteri şikâyetleri konusunda tutumun önemli belirleyicileri, müşterinin şikâyet etmenin iyi bir davranış olduğuna dair inanışı ile şikâyetinin işletme tarafından çözüleceğine ve olumlu bir şekilde sonuçlanacağına ilişkin değerlendirmesi olacaktır. Restoranlar bağlamında yapılan araştırmalar, bireyin çözüm elde edeceğine ilişkin güven duygusuna sahip olması (Su ve Bowen 2001) veya şikâyeti sonucunda olumlu çıtılar (zararın tazmini; takdir görme veya aynı hatanın tekrarlanmasını önleme gibi) elde edeceğine inanması durumunda (Velazquez vd. 2010) şikâyet etme eğilimin de arttığını göstermiştir. Bunun yanı sıra restoran işletmeciliği alanında birkaç araştırma doğrudan tutum ve şikâyet etme niyeti arasındaki ilişkiyi incelemiştir. Buna göre Cheng vd. (2005) ve Kim ve Boo (2011) şikâyete ilişkin tutumun şikâyet etme niyetini olumlu yönde etkilediğini saptamış iken Kim ve Chen (2010) şikâyete ilişkin olumlu tutum sahibi olmanın restoranlarda şikâyeti dillendirme davranışını olumlu yönde etkilediğini gösteren bulgular elde etmiştir. Buna karşın Cheng ve Lam (2008) tutum ile şikâyet etme niyeti arasında anlamlı bir ilişki tespit edememiştir. Genel olarak bakıldığında alanyazında tutumun restoranlarda müşterilerin şikâyet etme niyetlerini açıklayan başlıca faktörlerden biri olduğu kabul edilmektedir. Buradan hareketle çalışmanın ilk hipotezi aşağıdaki gibi kurulmuştur.

\section{H1: Şikâyete ilişkin tutum, restoran müşterilerinin şikâyet etme niyetlerini etkilemektedir.}

Öznel normlar, bireyin diğer insanların normatif beklentilerine yanit verme konusundaki motivasyonu ile ilgilidir (Lodorfos ve Dennis 2008). Birey kendisini yakın hissettiği ya da saygı duyduğu diğer insanların belirli bir davranışı göstermesine dair beklentilerine yanıt olarak bazı davranışları sergileyebilmektedir (Bagozzi vd. 2000). Böylece öznel normlar, bireylerin bazı davranışları göstermesi ya da göstermemesi yönünde bir sosyal bask1 oluşturmaktadır. Benzer baskılar şikâyet davranışı için de ortaya çıkabilmekte ve birey, önem verdiği diğer insanların memnun olmadığ şikâyetini dile getirmesi gerektiği yönündeki beklentisine yanıt olarak şikâyet davranışı sergileyebilmektedir. Jones vd. (2002) tarafından da belirtildiği gibi restoranlarda müşterilerin hangi şikâyet dav- 
ranışını sergileyecekleri başkalarının etkisi altında kalma durumlarına bağlı olabilmektedir. Benzer şekilde öznel normların şikâyet etme niyeti üzerindeki etkisini PDK kapsaminda test eden Cheng vd. (2005) ile Cheng ve Lam (2008) sosyal baskıların restoran müşterilerinin şikâyete ilişkin niyetlerini belirlediğini ortaya koymuştur. Buna karşın Wei vd. (2012) restoranlarda birlikte yemek yenen diğer bireylerin şikâyete ilişkin tutumlarının (olumlu ya da olumsuz) bireyin şikâyet davranışı (dillendirme, ağızdan ağıza olumsuz iletişim veya çıkış) üzerindeki etkisini gösterecek bir bulguya ulaşılamamıştır. Araştırmacılar şikâyet davranışı üzerinde sosyal baskıların varlığı konusunda kısmen çelişkili bulgular elde etmiş olmasına rağmen ilgili alanyazındaki araştırmalar öznel normları şikâyete ilişkin niyetin belirleyicileri arasında saymaktadır. Şu halde araştırmanın ikinci hipotezi aşağıdaki gibi yazılabilir.

H2: Öznel normlar, restoran müşterilerinin şikâyete ilişkin niyetlerini etkilemektedir.

Bireyin sergileyeceği davranışa ilişkin performansın kendi kontrolü altında olup olmadığı ile ilgili algılaması onun algılanan davranışsal kontrol düzeyini göstermektedir. Birey, davranışı kolaylıkla gerçekleştirip gerçekleştiremeyeceğini ve davranışı gerçekleştirmek için gerekli kaynak ve becerilere sahip olup olmadığını değerlendirerek bu algılamasını oluşturmaktadır. Şikâyet davranışının gerçekleştirilmesinde bireyin şikâyet etmenin kolay olup olmadığına ilişkin algılaması önemli bir faktör olabilmektedir (Kim ve Chen 2010). PDK kapsamında da algılanan davranışsal kontrolün restoran müşterilerinin şikâyet etme niyetlerinin önemli bir belirleyicisi olduğu hem Cheng vd. (2005) hem de Cheng ve Lam (2008) tarafından elde edilen görgül bulgularla ortaya konmuştur. Bir başka anlatımla, restoran müşterilerinin algılanan davranışsal kontrol düzeyi arttıkça şikâyet etme niyetleri de güçlenmektedir. Şu halde, araştırmanın üçüncü hipotezi aşağıdaki gibidir.

H3: Algilanan davranışsal kontrol, restoran müşterilerinin şikâyete ilişkin niyetlerini etkilemektedir.

Restoranlarda müşteri şikâyetlerinin belirleyicilerini inceleyen araştırmacıların bir kısmı müşterilerin kişilik özelliklerinin şikâyet etme niyetlerini etkileyebileceği yönünde görüşler sunmaktadır.
Söz gelimi, Jones vd. (2002) fiyat bilinci (müşterilerin aldığı hizmetin kalitesini değerlendirmede fiyatın rolü); psikolojik baskı hissi (müşterinin yakın ilişki içerisinde olduğu kişilerin fikrini alırken hissettiği sosyal baskı ve stres) ve kalite bilinci (müşterinin aldığı hizmetin kalitesini değerlendirebilme becerisi) şeklindeki faktörlerin bireyin kişilik özelliklerini tanımlamada kullanılabileceğini ve bunların şikâyet etme davranışının belirleyicisi olarak dikkate alınabileceklerini ifade etmektedir. Daha yakın dönemde gerçekleştirilen araştırmalarda ise benlik kurgusu (Wei vd. 2012) ve kendini önemseme (Kim ve Chen 2010) değişkenlerinin kişilik özelliklerinin birer temsilcisi olarak incelendiği görülmektedir.

Wei ve arkadaşlarına (2012) göre benlik kurgusu, bireyin kararını ne dereceye kadar diğer insanlardan bağımsız ya da diğer insanlara bağımlı kalarak verebileceği ile ilgilidir. Bu durumda benlik kurgusu yüksek olan bireylerin kendi düşüncelerine dayanarak karar verme ve davranma olasılıkları yüksektir. Aksine benlik kurgusu zayıf bireylerin kararları diğer insanların düşüncelerine bağlı kalabilmektedir. Wei vd. (2012) benlik kurgusu yüksek bireylerin şikâyetlerini dillendirme eğilimlerinin de yüksek olacağını belirtmiş ve bu hipotezlerini görgül bulgularla da desteklemişlerdir. Kim ve Chen de (2010) benzer bir yaklaşımla kendilerini önemseyen müşterilerin şikâyet ederken ve maruz kaldıkları hatanın düzeltilmesini talep ederken daha az sıkıntı hissi duyacaklarını ileri sürmüştür. Elde ettikleri bulgular, kendini önemseme değişkeninin şikâyeti dillendirme üzerindeki etkisine ilişkin bir destek sağlamasa da kendini önemseyen restoran müşterilerinin etraflarına restoranla ilgili olumsuz düşüncelerini iletme eğilimlerinin yüksek olduğunu göstermiştir. İlgili alanyazın restoran müşterilerinin şikâyet etme eğilimlerinin önemli belirleyicilerinden biri olarak kişilik özelliklerine atıfta bulunsa da bu konuda yapılan çalışmaların sayısının azlı̆̆ı dikkat çekmekte ve elde edilen bulguların tutarlılığının tartışmalı olduğu anlaşılmaktadır. Ancak son dönemde bireylerin kendilerini ne kadar önemli gördükleri konusu ilgi görmeye başlamıştır. Bu sebeplerle, bu çalışmada da kendini önemseme değişkeni ile şikâyet etme niyeti arasında bir ilişki olabileceği düşünülerek aşağıdaki hipotez geliştirilmiştir. 
H4: Kendini önemseme, restoran müşterilerinin şikâyet etme niyetlerini etkilemektedir.

Az sayıda araştırmaya konu olmakla birlikte müşterilerin tüketici olarak haklarını ve şikâyetlerini nereye ve nasil yapabileceklerini bilme anlamında sahip oldukları enformasyonun düzeyi de şikâyet etme niyetini etkileyen değişkenler arasında yer almaktadır. Tüketicilerin sahip olduğu enformasyonun düzeyi arttıkça şikâyeti dillendirme eğilimlerinin de artması beklenmektedir. Velazquez vd. (2010) tarafından bu yönde geliştirilmiş olan hipotez de görgül bulgularla destek bulabilmiştir. Müşterilerin enformasyon düzeyleri, onların d1şarıda yemek yeme sıklığı ve/veya restoranlarda şikâyetçi olma konusundaki deneyimlerinin sayısı ile yakından ilişkilidir. Müşteriler özellikle geçmiş şikâyet deneyimleri kapsamında şikâyet etme yolları ve şikâyet sonrası elde edecekleri çıtılar konusundaki bilgilerini genişletebilmektedir (Kim ve Boo 2011). Bu öğrenme sürecinde deneyimlerin ne sıklıkla yaşandığı da önemlidir. Cheng vd. (2005) tarafından da vurgulandığı gibi geçmişte şikâyeti dillendirme davranışının sıklıkla yapılmış olması, benzer bir davranışın gelecekte yaşanması olasılığını arttıracaktır. Başka bir ifade ile geçmişte yapılan şikâyetlerin sıklığı, müşterinin şikâyet etme eğiliminin güçlenmesine neden olacaktır. Cheng vd. (2005) tarafından elde edilen bulgular da geçmişteki şikâyet deneyimlerinin ne sıklıkta yaşandığının restoran müşterilerinin şikâyetlerini dillendirme niyetlerini anlamlı bir şekilde açıklayan bir değişken olduğunu göstermiştir. Benzer bir bulgu Kim ve Boo'nun (2011) çalışmasında da yer almaktadır. Şikâyet deneyiminin artışı ise dışarıda yemek yeme sıklığ 1 ile açıklanabilmektedir. Gursoy vd. (2003) dışarıda daha sık yemek yiyen müşterilerin çok çeşitte ve sayıda restoran hizmetini deneyimleyebileceğini, dolayısıyla şikâyete konu olan hatalara maruz kalma ve bunlar karşısında nasıl davranacağını öğrenme konusundaki olasılıklarının da artacağını belirtmektedir. Bu açıklamalar ışığında dışarıda yemek yeme sıklığının müşterilerin enformasyon düzeyini ve dolayısıyla şikâyet etme eğilimlerini arttıracağı söylenebilir. Bu ilişkiyi test eden Jones vd. (2002), dışarıda yemek yeme sıklığı ile müşterilerin restoranlarda şikâyet etme davranışları arasında anlamlı bir ilişki saptayamazken, Gursoy vd. (2003) tarafından elde edilen bulgular dışarıda yemek yeme sıklığının şikâyet davranışı- nı açıklamada önemli bir değişken olduğuna işaret etmektedir. İlgili alanyazında enformasyon düzeyinin şikâyet etme niyeti üzerindeki etkileri konusunda teorik temeller (önceki şikâyet deneyimi ve dışarıda yemek yeme sıklığı) açıklanmış olsa da bu ilişkiyi doğrudan test eden çalışma sayısının azlığ1 dikkat çekmektedir. Bu nedenlerle bu çalışmada aşağıdaki hipotez öne sürülmektedir.

\section{H5: Enformasyon düzeyi, restoran müşterilerinin şikâyet etme niyetlerini etkilemektedir.}

Alanyazın taraması ve geliştirilen hipotezlerin 1şı̆̆ında araştırma modeli Şekil 1'deki gibi gösterilebilir. Bu modele göre restoran müşterilerinin şikâyet etme niyetleri, şikâyete ilişkin olumlu tutumlara sahip oldukları oranda güçlenecektir (Hipotez 1). Öznel normlar kapsamında şikâyet etmeye ilişkin güçlü sosyal baskılarla karşılaştıkları nispette şikâyet etme niyetleri artacaktır (Hipotez 2). Müşterilerin şikâyet davranışlarını kontrol edebileceklerine ilişkin algılamaları kuvvetlendikçe şikâyet etme niyetleri de güçlenecektir (Hipotez 3). Bunlara ek olarak kendini önemseyen bireylerin şikâyet etme niyetlerinin daha güçlü olması beklenmektedir (Hipotez 4). Nihai olarak şikâyet konusundaki deneyimler ile elde edilen enformasyon düzeyi de restoran müşterilerinin şikâyet eğilimlerini olumlu yönde etkileyen bir değişkendir (Hipotez 5).

\section{ARAŞTIRMANIN YÖNTEMI}

Araştırma modeli çerçevesinde tanımlanan kavramsal modeli görgül bulgular ışığında test etmek amacıyla nicel araştırma yaklaşımı benimsenmiş ve aşağıda yaklaşımın ana bileşenleri (örneklem, veri toplama aracı ve analizler) açıklanmıştır.

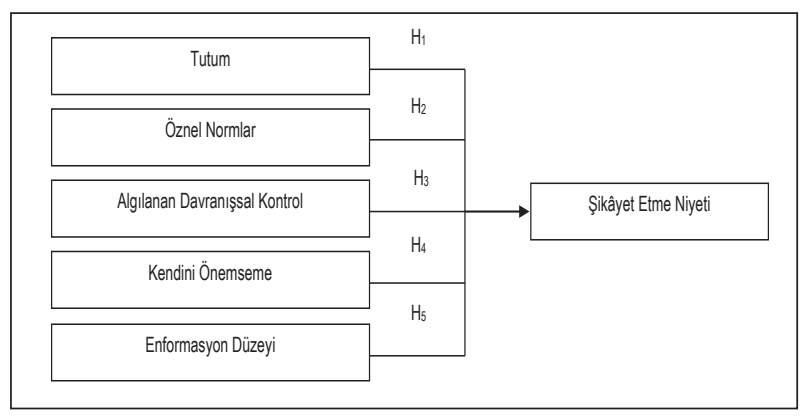

Şekil 1. Araştırma Modeli 


\section{Örneklem}

Çalışmanın örneklemi oluşturulurken amaçsal ve kolayda örnekleme yöntemleri birlikte kullanılmıştır. Çalışmanın örneklemine dahil edilecek bireylere ilişkin ölçütler, amaçsal örnekleme yöntemi kapsamında tespit edilmiştir. Daha açık bir ifade ile çalışmanın örneklem çerçevesi oluşturulurken örnekleme dahil edileceklerin 18 yaşından büyük ve ayda en az bir kez dişarıda yemek yiyen bireyler olmasına dikkat edilmiştir. Dışarıda yemek yeme sıklığı arttığında şikâyete konu olacak hatalara maruz kalma olasılığının artacağı varsayıldığından dışarıda yemek yeme sıklığı, örneklemin belirlenmesinde önemli bir ölçüt olarak alınmıştır. Soru formlarının geri dönüş oranını yüksek tutabilmek amacı ile örnekleme alınacak kişilere ulaşmak üzere kolayda örnekleme yöntemi tercih edilmiştir.

İlgili alanyazındaki araştırmalara göre restoranlarda şikâyet etme oranının \%40 düzeyinde olduğu görülmektedir. Sözgelimi, bu oranın Wildes ve Seo'nun (2001) çalışmasında \%32 seviyesinde; Heung ve Lam (2003) ile Kitapçı'nın (2008) araştırmalarında ise $\% 40$ düzeyinde olduğu saptanmıştır. Bu bilgi de kullanılarak oran yönteminden yararlanılmak suretiyle güven aralığ1 $\% 95$ ve hata payı $\% 5$ düzeyinde olmak üzere ( $\mathrm{p}=0,40$ ve $\mathrm{q}=0,60)$ örnekleme dahil edilecek kişi sayısının en az 369 olması gerektiği hesaplanmıştır. Olası veri kayıpları (eksik doldurulmuş formlar ve uç değerlerin atılması) dikkate alınarak 500'den fazla sayıda anket formunun dağıtılması hedeflenmiştir. Soru formları büyük bir şehrin işlek bir caddesinde 2013 yılının Temmuz ayında hafta içi dört gün boyunca 10.0019.00 saatleri arasında dağıtılmıştır. Büyük bir şehrin ve işlek bir caddenin seçilmiş olması belirli bir sıklıkta dışarıda yemek yiyen insanlara burada ulaşılabilmesinin daha kolay olacağ düşüncesine dayanmaktadır. Potansiyel katılımcılara yaklaşılarak önce araştırmanın amacı açıklanmış ve elde edilecek verilerin sadece bilimsel araştırma amacı ile kullanılacağı vurgulanmış, ardından araştırmaya katılmak isteyip istemedikleri sorulmuştur. $\mathrm{Bu}$ çerçevede 582 kişiye anket formu dağıtılabilmiştir. Yapılan inceleme sonucu 17 anket formunun eksik doldurulması neticesinde elenmesine karar verilmiştir. Uç değerleri saptamak üzere ölçek toplam puanları üzerinden Mahalanobis uzaklığı hesaplanmış ve bu hesaplamalar sonrası değeri $0,1^{\prime}$ den küçük olanların elenmesi sonucu 190 anket formu daha analiz dışı bırakılmıştır. Nihayetinde ilerleyen analizlere dahil edilebilecek 375 adet anket formu geçerli olarak kabul edilmiştir.

Ulaşılan bu sayının verilerin analizinde kullanılacak istatistikî modellerin gerektirdiği asgari örneklem büyüklüğü şartını karşılayıp karşılamadığına da bakmak gerekir. İlgili alanyazın analizler için örneklem büyüklügünün değişken sayısına oranla belirlenebileceğini söylemektedir (Jayaram vd. 2004). Buna göre normal dağılımda değişken sayısının beş katı, diğer dağılımlarda ise on katı örneklem büyüklügüü önerilmektedir (Bentler ve Chau 1987). Anderson ve Gerbing (1988) ise gözlem sayısının en az 150 olması gerektiğini belirtmektedir. Bu çalışmada ölçeklerdeki toplam madde sayısı 19 olduğundan 375 adet gözlemin asgari sayının üzerinde ve yeterli olduğu anlaşılmaktadır.

\section{Veri Toplama Aracı}

Bu çalışmada veri toplamak amaciyla anket yönteminden yararlanılmıştır. Soru formu üç bölümden oluşmaktadır. İlk bölüm soru formunun hemen başında bulunmakta ve araştırmanın amacını kısaca ifade eden ve verilerin üçüncü kişilerce paylaşılmayacağını belirten açıklamadan oluşmaktadır. İkinci bölümde araştırma modelinin bağımlı ve bağımsız değişkenlerine ilişkin dört ölçek yer almaktadır. Üçüncü bölümde ise katılımcıların yaş, cinsiyet, gelir, meslek ve eğitim durumu gibi demografik özelliklerine ilişkin sorular bulunmaktadır. Yine aynı bölümde katılımcıların dışarıda yemek yeme sıklıkları ve dışarıda yemek yeme için ortalama harcamalarına ilişkin sorular da yer almaktadır. Dışarıda yemek yeme sıklığı ortalama olarak ayda kaç kez dışarıda yemek yendiği; ortalama harcama da dışarıda yemek yendiğinde tek seferde ortalama ne kadar harcama (TL) yapıldı ğı şeklinde sorulmuştur.

Araştırma modelinin bağımsız değişkenlerinden ikisi olan algılanan davranışsal kontrol ve öznel normlar Cheng vd. (2005) ile Cheng ve Lam'ın (2008) çalışmalarında kullandıkları dörder maddeli ölçekler ile ölçülmüştür. Diğer bağımsız değişken olan tutum ise Velazquez vd. $(2006$; 2010) çalışmalarında kullanılmış olan dört madde ile ölçülmüştür. Diğer bağımsız değişkenlere ilişkin ölçekler de ilgili alanyazındaki mevcut çalışmalardan derlenmiştir. İki maddeden oluşan enformasyon düzeyi ölçeği Velazquez vd. (2010) çalışmasından 
ve yine iki maddeli bir ölçek olan kendini önemseme ölçeği de Kim ve Chen'in (2010) çalışmasından alınmıştır. Araştırma modelinin bağımlı değişkeni olan şikâyete ilişkin niyetin ölçümünde de Velazquez vd. (2010) çalışmasında katılımcıların doğrudan restoran yönetimine şikâyet etme niyetlerini ölçmede kullandıkları üç maddeli ölçekten yararlanılmıştır. Ölçeklerde kullanılan maddelere şu örnekler verilebilir: Algılanan davranışsal kontrol için "Memnun olmadığım bir yemek deneyimini restoran yöneticisine söyleyip söylememek çoğunlukla bana bağglıdır"; tutum için "Bir restoranda sorun yaşadığımda çoğunlukla şikâyet ederim, para iadesi veya yemeğin değiştirilmesini isterim"; öznel normlar için "Düşüncesine önem verdiğim kişiler; memnuniyetsizliğimi restoran yöneticisine söylemem gerektiğini düşünür"; enformasyon düzeyi için "Bir şikâyetin nasıl yapılacağını bilirim"; kendini önemseme için "Diğer insanların izinden gitmektense kendi tarzımın olmasın tercih ederim" ve niyet için "Restoranda bir problem yaşadtğımda hataların düzeltmesi için problemle ilgili yorumlarımı restoran yöneticisine söylerim".

Ölçekler Türkçe ve İngilizce dillerine hakim iki öğretim elemanı tarafından Türkçeye çevrilmiştir. Ölçeklerin çevirileri beş öğretim üyesinin görüşüne sunulmuştur. Uzman görüşleri doğrultusunda ölçeklerdeki ifadelerin çevirilerinde kullanılan birkaç sözcük değiştirilmiş ve Türkçe olarak daha anlaşılır hale gelmeleri sağlanmıştır. Altı ölçekte yer alan toplam 19 ifadeden 18'ine katılımciların 5'li Likert derecelendirmesi ile (1=Tamamen katılmıyorum ve $5=$ Tamamen katiliyorum) cevap vermeleri istenmiştir. Algılanan davranışsal kontrol ölçeğinde yer alan ve katılımciların memnuniyetsizliklerini restoran yöneticilerine söylemenin ne dereceye kadar kendi kontrollerinde olduğunu ölçen madde ise 5 noktalı ölçek (1=Tamamen kontrolümün d1şında ve $5=$ Tamamen kontrolümün altında) üzerinden cevaplanmıştır. PDK'nın geliştiricileri tarafından tutum, öznel normlar ve algılanan davranışsal kontrol değişkenlerinin ölçümünde iki kutuplu semantik diferansiyel ölçeğinin kullanılması önerilse de ölçeklerin çevirilerine ilişkin uzman görüşlerinin alınması sırasında iki kutuplu ölçeğin hedef katılımclar tarafından anlaşılmasının ve yanıtlanmasının zor olabileceği belirtilmiştir. Bu nedenle bu ifadeler için 5 noktalı ölçek kullanılmıştır.

Soru formunun biçimini, formdaki ifadelerin anlaşılırlığını ve soruların sırasının uygunluğunu test etmek amacıyla 25 kişinin katılımı ile bir öntest gerçekleştirilmiştir. Ön-test ile birkaç sorunun ifade ediliş biçiminde küçük değişiklikler yapılmış, iki sorunun sırası değiştirilmiş ve soru formuna son şekli verilmiştir.

\section{Analizler}

Katılımcıların demografik özelliklerine ilişkin veriler, frekans ve yüzde dağılımları ile incelenmiştir. Araştırma modeline ilişkin analizler ise Anderson ve Gerbing'in (1988) önerisine uygun olarak iki aşamada gerçekleştirilmiştir. İlk aşamada doğrulayıcı faktör analizi (DFA) yardımı ile ölçüm modeli test edilmiş ve ölçümün geçerliliği ve güvenirliliğine ilişkin bulgular elde edilmiştir. Bunun için öncelikle ölçek maddelerinin ilgili örtük değişkeni güvenilir bir şekilde yansıtıp yansıtmadığı standartlaştırılmış faktör yüklerine bakılarak incelenmiş; değişkenler için yapı güvenirliliği katsayıları, Cronbach's Alpha değerleri ve ortalama açıklanan varyans değerleri hesaplanmıştır. Yakınsama ve ayrışım geçerlilikleri için ortalama açıklanan varyans değerleri kullanılmıştır. İkinci aşamada Yapısal Eşitlik Modeli (YEM) yardımı ile araştırmanın hipotezleri test edilmiştir. Uyum istatistiklerine bakılarak modelin uyumu değerlendirilmiş ve ardından standartlaştırılmış yol katsayılarının incelenmesi ile hipotezlerin öngördüğü ilişkilerin istatistikî açıdan değerlendirmesi yapılmıştır.

\section{BULGULAR VE TARTIŞMA}

Bulguların sunumu katılımcıların demografik özelliklerine ilişkin elde edilen sonuçlarla başlamakta ve çalışmada kullanılan ölçeklerin geçerlilik ve güvenirliliklerine ilişkin bilgilerle devam etmektedir. Bu kısmın sonunda araştırma hipotezlerinin testine ilişkin bulgular ilgili alanyazındaki önceki araştırmaların bulguları ile karşılaştırılarak sunulmaktadır.

\section{Katılımcıların Demografik Özelliklerine İlişkin Bulgular}

Katılımcıların demografik özelliklerine ilişkin bilgiler Tablo 3'te yer almaktadır. Katılımciların $\% 60,5^{\prime}$ inin erkek ve \%73,5'inin de lisans veya lisansüstü mezunu olduğu görülmektedir. Çalışmaya katılanların \%38,3'ünün 25-34 yaş aralığında olduğu anlaşılmaktadır. Katılımcıların meslekleri ince- 
lendiğinde \%22,9'unun serbest meslek sahibi olduğu göze çarpmaktadır. Katılımcıların \%32,5'inin 2000-2999 TL civarında aylık gelir elde ettiği ve \%41,1'inin ayda 1-5 kez dışarıda yemek yediği görülmektedir. Dışarıda yemek yendiğinde tek seferde ortalama harcama tutarı 50 TL'ye kadar olanların örneklemin çoğunluğunu (\%70) oluşturduğunu söylemek mümkündür.

\section{Güvenirlilik ve Geçerliliğe İlişkin Bulgular}

Ölçüm modelinin testi için gerçekleştirilen DFA sonuçları Tablo 4'te sunulmaktadır. Bu sonuçlar standartlaştırılmış faktör yük değerleri düşük olan iki ölçek maddesinin (algılanan davranışsal kontrol ölçeğinden bir madde ve tutum ölçeğinden bir madde) çıkarılması ile elde edilmiştir. Biri hariç (AlgKont3=0,42) olmak üzere tabloda gösterilen ölçek maddelerine ait tüm faktör yükleri 0,50'nin üzerindedir. Ölçek maddelerinin tamamı yüksek $\mathrm{t}$ değerlerine sahiptir ve istatistiki açıdan anlamlı bir şekilde $(p<0,05)$ ilgili örtük değişkene yüklenmiştir. Diğer taraftan ölçek maddeleri ile ilişkili olarak çok değişkenli normallik varsayımın karşılanıp karşılanmadığ 1 da dikkate alınması gereken bir husustur. Bu nedenle Tablo 4'te ölçek maddelerine ilişkin çarpıklık ve basıklık katsayıları verilmiş ve bu değerlerin çarpıklık için 2'den; basıklık için de 7'den küçük olduğu (Şencan 2005) görüldügüünden çok değişkenli normallik varsayımı açısından bir sorun olmadığı sonucuna varılmıştır. Örtük değişkenlere ilişkin yapı güvenilirliği katsayıları 0,62 ile 0,83 arasında değişirken; Cronbach's Alpha değerlerinin de 0,61 ile 0,84 arasında olduğu görülmektedir. Bu değerler de ölçeklerin kabul edilebilir seviyede güvenilir olduklarına işaret etmektedir (Murphy ve Davidshofer 1988). Genel olarak modele ilişkin uyum iyiliği istatistikleri de (Ki kare değeri $=190,25$; serbestlik derecesi $=104$; ki kare/ serbestlik derecesi $=1,8$; RMSEA $=0,047$; $\mathrm{CFI}=0,98$; GFI $=0,94$; NFI $=0,96)$ ölçüm modelinin kabul edilebilir bir model olduğunu göstermektedir.

Ölçümün yakınsama ve ayrışma geçerliliğine ilişkin bir değerlendirme yapmak üzere ortalama açıklanan varyans değerleri ve değişken çiftleri arasındaki korelasyonların kareleri hesaplanmıştır ve sonuçlar Tablo 5'te sunulmaktadır. Yakınsama geçerliliğini göstermek için ortalama açılanan varyans değerlerinin 0,50'nin üzerinde olması gerekmektedir. Tablo 5'deki sonuçlara göre algılanan davranışsal kontrol ve tutum için bu değerlerin s1rası ile 0,37 ve 0,35 olduğu görülmektedir. Diğer ölçekler için ise kabul edilebilir değerin üzerinde ol-

Tablo 3. Demografik Bulgular

\begin{tabular}{|c|c|c|c|}
\hline & Değişkenler & Frekans & $\%$ \\
\hline \multirow[t]{3}{*}{ Cinsiyet } & Erkek & 227 & 60,5 \\
\hline & Kadın & 148 & 39,5 \\
\hline & Toplam & 375 & 100 \\
\hline \multirow[t]{6}{*}{ Yaş } & $18-24$ & 69 & 18,5 \\
\hline & $25-34$ & 143 & 38,3 \\
\hline & $35-44$ & 78 & 20,9 \\
\hline & $45-54$ & 51 & 13,7 \\
\hline & $55+$ & 32 & 8,6 \\
\hline & Toplam & 373 & 100 \\
\hline \multirow[t]{5}{*}{ Eğitim } & İlköğretim & 21 & 5,7 \\
\hline & Lise & 77 & 20,8 \\
\hline & Lisans & 225 & 61,0 \\
\hline & Lisansüstü & 46 & 12,5 \\
\hline & Toplam & 369 & 100 \\
\hline \multirow[t]{6}{*}{ Gelir } & $0-999$ & 18 & 6,7 \\
\hline & 1000-1999 & 60 & 21,8 \\
\hline & $2000-2999$ & 89 & 32,5 \\
\hline & $3000-3999$ & 46 & 16,7 \\
\hline & $4000+$ & 61 & 22,3 \\
\hline & Toplam & 274 & 100 \\
\hline \multirow[t]{9}{*}{ Meslek } & Serbest Meslek & 85 & 22,9 \\
\hline & Memur & 69 & 18,6 \\
\hline & İşçi & 59 & 15,9 \\
\hline & Öğrenci & 50 & 13,5 \\
\hline & Yönetici /Müdür & 46 & 12,4 \\
\hline & Mühendis / Mimar & 33 & 8,9 \\
\hline & Emekli & 21 & 5,7 \\
\hline & Ev Hanımı & 8 & 2,1 \\
\hline & Toplam & 371 & 100 \\
\hline \multicolumn{4}{|c|}{ Dışarıda Yemek } \\
\hline \multirow[t]{8}{*}{ Yeme Sıklığı } & $1-5$ & 146 & 41,1 \\
\hline & $6-10$ & 97 & 27,2 \\
\hline & $11-15$ & 47 & 13,2 \\
\hline & $16-20$ & 30 & 8,4 \\
\hline & $21-25$ & 10 & 2,8 \\
\hline & $26-30$ & 22 & 6,2 \\
\hline & $30+$ & 4 & 1,1 \\
\hline & Toplam & 356 & 100 \\
\hline \multicolumn{4}{|l|}{ Ortalama } \\
\hline \multirow[t]{3}{*}{ Harcama } & 50 TL'ye kadar & 251 & 70 \\
\hline & 50 TL'nin üzeri & 107 & 30 \\
\hline & Toplam & 358 & 100 \\
\hline
\end{tabular}


Tablo 4. Ölçüm Modeli ile İlgili Analiz Sonuçları

\begin{tabular}{|c|c|c|c|c|c|c|}
\hline & S.F.Y & $t$ değeri & $\begin{array}{c}\text { Yapı } \\
\text { Güvenilirliği }\end{array}$ & $\begin{array}{l}\text { Cronbach's } \\
\text { Alpha }\end{array}$ & Çarpıklık & Basıklık \\
\hline Algılanan Davranışsal Kontrol & & & 0,62 & 0,61 & & \\
\hline Algkont1 & 0,56 & 10,31 & & &,- 58 & $-1,05$ \\
\hline Algkont2 & 0,78 & 14,39 & & &,- 83 &,- 55 \\
\hline Algkont3 & 0,42 & 7,52 & & &,- 37 & $-1,16$ \\
\hline Tutum & & & 0,62 & 0,61 & & \\
\hline Tut1 & 0,60 & 10,94 & & &,- 30 & $-1,10$ \\
\hline Tut2 & 0,56 & 10,08 & & &,- 39 &,- 96 \\
\hline Tut3 & 0,61 & 11,15 & & &,- 06 & $-1,26$ \\
\hline Öznel Normlar & & & 0,80 & 0,80 & & \\
\hline Öznorm1 & 0,75 & 15,53 & & &,- 94 & 25 \\
\hline Öznorm2 & 0,77 & 15,97 & & &,- 75 &,- 05 \\
\hline Öznorm3 & 0,70 & 14,29 & & &,- 68 &,- 23 \\
\hline Öznorm4 & 0,61 & 12,00 & & &,- 52 &,- 37 \\
\hline Enformasyon Düzeyi & & & 0,80 & 0,80 & & \\
\hline Enfdüz1 & 0,76 & 15,16 & & &,- 55 &,- 55 \\
\hline Enfdüz2 & 0,87 & 17,30 & & & $-1,03$ & ,32 \\
\hline Kendini Önemseme & & & 0,70 & 0,67 & & \\
\hline Kendönem1 & 0,59 & 10,31 & & &,- 39 &,- 95 \\
\hline Kendönem2 & 0,86 & 13,78 & & & $-1,13$ &, 51 \\
\hline Niyet & & & 0,83 & 0,84 & & \\
\hline Niy1 & 0,79 & 17,20 & & & $-1,01$ &,- 03 \\
\hline Niy2 & 0,82 & 18,12 & & &,- 76 &,- 64 \\
\hline Niy3 & 0,78 & 17,08 & & &,- 59 &,- 77 \\
\hline
\end{tabular}

(S.F.Y.=Standartlaştırılmış faktör yükleri; Uyum istatistikleri: $\mathrm{x}^{2}=190,26 ; \mathrm{p}=0,000$, serbestlik derecesi $=104 ; \mathrm{x}^{2} /$ serbestlik derecesi $=1,8$; RMSEA $=0,047$; NFI $=0,96 ; \mathrm{GFI}=0,94 ; \mathrm{CFI}=0,98$ )

dukları anlaşılmaktadır. Fornell ve Larcker'a (1981) göre ortalama açıklanan varyans değerlerinin değişken çiftleri arasındaki korelasyonların karelerinden büyük olması halinde ayrışma geçerliliği gösterilmiş olmaktadır. Tablo 5'teki sonuçlar da her bir örtük değişkene ilişkin ortalama açıklanan varyans değerinin o değişkenle diğer değişkenlerin korelasyonlarının karesinden büyük olduğunu göstermekte ve dolayısıyla tüm ölçeklerin ayrışma geçerliliğinin sağlandığına ilişkin kanıtlar sunmaktadır.

Ölçüm modelinin güvenirlilik ve geçerliliğine ilişkin değerlendirmeler sonucu algılanan davranışsal kontrol ve tutum ölçeklerinin yakınma geçerlilikleri tam olarak gösterilememiş olsa da güve- nirlilik ve ayrışma geçerliliği açısından kabul edilebilir değerlere sahip oldukları görülmüştür. Bu iki değişken PDK'nın da temel iki değişkeni olduğundan yakınsama geçerliliği açısından sorunları olmasına karşın ileriki analizlere dahil edilmelerinin uygun olacağına karar verilmiştir.

\section{Hipotezlerin Testi}

Araştırma modelinde öngörülen ilişkilerin testi için kurulan YEM'e ilişkin sonuçlar Tablo 6'da sunulmaktadır. Uyum istatistikleri (Ki kare değeri=249,98; serbestlik derecesi $=114$; Ki kare/serbestlik derecesi $=2,23$; RMSEA $=0,056$; GFI $=0,93$; $\mathrm{NFI}=0,95$; $\mathrm{CFI}=0,97$ ) modelin verilere uyum sağla- 
Bireysel ve Davranışsal Faktörlerin Restoran Müşterilerinin Şikâyet Etme Niyetlerine Etkisi

Tablo 5. Değişken Çiftleri Arasındaki Korelasyonların Kareleri ve Ortalama Açılanan Varyans

\begin{tabular}{|c|c|c|c|c|c|c|}
\hline & 1 & 2 & 3 & 4 & 5 & $\begin{array}{r}\text { Ortalama açıklanan } \\
\text { varyans }\end{array}$ \\
\hline Algılanan davranışsal kontrol & & & & & & 0,37 \\
\hline Tutum & 0,24 & & & & & 0,35 \\
\hline Öznel normlar & 0,07 & 0,04 & & & & 0,50 \\
\hline Enformasyon düzeyi & 0,17 & 0,14 & 0,12 & & & 0,67 \\
\hline Kendini önemseme & 0,06 & 0,06 & 0,14 & 0,13 & & 0,54 \\
\hline Niyet & 0,28 & 0,29 & 0,18 & 0,25 & 0,19 & 0,63 \\
\hline
\end{tabular}

(1=Algılanan davranışsal kontrol; 2=Tutum; 3=Öznel normlar; 4=Enformasyon düzeyi; 5=Kendini Önemseme)

dığını göstermektedir. Değişkenler arasındaki ilişkilere dair bulgulara göre standartlaştırılmış yol katsayılarının değerlerinin 0,52 ile 0,77 arasında olduğu ve $t$ değerleri açısından da bunların istatistikî olarak anlamlı bulunduğu tespit edilmiştir.

Tablo 6'daki bulgulardan ilki tutumun şikâyet etme niyetini güçlü bir şekilde $(\beta=0,77 ; t=9,41)$ etkilediğini ortaya koymaktadır. Buna göre şikâyete ilişkin olumlu tutum sahibi olan cevaplayıcıların restoranlarda şikâyet etme niyetleri de güçlü olmaktadır. Böylece araştırmanın ilk hipotezi araştırma bulgularından destek bulabilmiştir. Bu sonuç Cheng vd. (2005); Kim ve Chen (2010); Kim ve Boo'nun (2011) araştırma bulguları ile tutarlılık gösterirken Cheng ve Lam'in (2008) bulgusu ile ters düşmektedir. Bunun bir nedeni iki araştırmanın örneklemlerinin farklı olması olabilir. Cheng ve Lam (2008) araştırmalarını Çinli restoran müşterileri üzerinde gerçekleştirmiştir ve yazarların da ifade ettiği gibi Çinliler sosyal baskılara oldukça açıktır. Kültürlerinde şikâyet etme yaygın biçimde kabul gören bir davranış değildir. Bu da onların şikâyete ilişkin tutum ve niyetlerini farklı şekillerde etkileyebilir. Cheng ve Lam'in (2008) çalışması dışında, bu araştırma bulguları ile önceki çalışmaların bulgularının büyük oranda örtüşmüş olması PDK kapsamında tutumun şikâyet etmeye ilişkin niyetin önemli bir belirleyicisi olarak kabul edilmesi gerekliliğini pekiştirmiştir. Böylece ilgili alanyazında kabul görmüş bir görüş olan şikâyetçi bireyler şikâyete yönelik olumlu tutum sahibi iken olumsuz tutum besleyenlerin memnuniyetsizliklerini bildirme konusunda isteksiz oldukları şeklindeki düşünce bu araştırma bulguları ile bir kez daha güçlü bir şekilde desteklenmiştir.

Araştırmanın ikinci hipotezi öznel normlar ile şikâyet etme niyeti arasında bir ilişki öngörmektedir. Tablo 6'daki bulgular da öznel normların şikâyet etme niyeti üzerindeki etkisini $(\beta=0,52$; $\mathrm{t}=8,38)$ göstermektedir. Bir başka anlatımla düşüncesine önem verdiği insanların şikâyet etmesi yönündeki baskılarına maruz kalan cevaplayıc1ların şikâyet etme niyetleri de güçlenmektedir. $\mathrm{Bu}$ durumda araştırmanın ikinci hipotezi de desteklenmiş olmaktadır. Bu bulgu Cheng vd. (2005) ile Cheng ve Lam'in (2008) çalışmalarında ulaştıkları bulgular ile uyumludur ve sosyal baskıların restoran müşterilerinin şikâyete ilişkin niyetlerini be-

Tablo 6. Yapısal Eşitlik Modeline İlişkin Sonuçlar

\begin{tabular}{lccr}
\hline Hipotezler & S.Y.K. & $t$ değeri & Sonuç \\
\hline 1. Tutum $\rightarrow$ Niyet & 0,77 & 9,41 & Desteklendi \\
\hline 2. Öznel normlar $\rightarrow$ Niyet & 0,52 & 8,38 & Desteklendi \\
\hline 3. Algılanan davranışsal kontrol $\rightarrow$ Niyet & 0,76 & 8,61 & Desteklendi \\
\hline 4. Kendini önemseme $\rightarrow$ Niyet & 0,60 & 6,77 & Desteklendi \\
\hline 5. Enformasyon düzeyi $\rightarrow$ Niyet & 0,66 & 9,96 & Desteklendi
\end{tabular}

(S.Y.K.=Standartlaştırılmış Yol Katsayıları; Uyum istatistikleri: $x^{2}=249,98$, Serbestlik derecesi $=114, x^{2} /$ serbestlik derecesi $=2,23$; RMSEA $=0,056$; GFI $=0,93$; NFI $=0,95$; CFI $=0,97$ ) 
lirlediğini bir kez daha ortaya koymuştur. Wei vd. (2012) çalışmasında bu baskılar, birlikte yemek yenen insanların şikâyete ilişkin tutumları şeklinde kavramsallaştırılmıştır ve şikâyet davranışı üzerinde etkilerinin olmadığı yönünde sonuçlara ulaşımıştır. Şu halde Wei vd.'nin (2012) bulguları ile bu çalışmanın bulguları arasında çelişki olduğu söylenebilir. Ancak şu hatırlatılmalıdır ki Wei vd. (2012) birlikte yemek yenen insanların şikâyete ilişkin tutumlarının etkisini yalıtarak ölçmemiş; aksine benlik kurgusu değişkeni ile etkileşimine göre şikâyet davranışı ile ilişkisini sınamışlardır. Bu nedenle bu iki çalışmanın bulguları arasında farklılık ortaya çıkmış olabilir.

Tablo 6'ya bakıldığında algılanan davranışsal kontrolün şikâyet etme niyetini olumlu yönde etkilediği $(\beta=0,76 ; t=8,61)$ görülmektedir. Bir başka ifade ile cevaplayıcıların bir restoranda şikâyet etme konusunda algıladıkları kontrolün seviyesinin artması onların şikâyet etme niyetlerinin de güçlenmesine yol açmaktadır. Bu durumda "algılanan davranışsal kontrol restoran müşterilerinin şikâyete ilişkin niyetlerini etkilemektedir" şeklindeki üçüncü hipotez de ilgili alanyazına (Cheng vd. 2005; Cheng ve Lam 2008; McQuilken ve Robertson 2011) uygun şekilde bu araştırmanın bulguları ile görgül destek bulabilmiştir. Cheng vd. (2005) alg1lanan davranışsal kontrolün farklı şikâyet davranışlarını (dillendirme; ağızdan ağıza olumsuz iletişim; çıkış) gösterme niyetinin belirleyicisi olduğunu Çinli tüketicilerin restoran deneyimleri üzerine yaptıkları araştırmalarında ortaya koymuştur. Benzer bir şekilde, Çinli restoran müşterileri ile gerçekleştirdikleri araştırmalarında Cheng ve Lam (2008) de algılanan davranışsal kontrolün şikâyet niyeti üzerindeki etkisini görgül bulgularla göstermişlerdir. Bu çalışma ile de Türkiye bağlamında restoran hizmetlerinin tüketiminde algılanan davranışsal kontrolün şikâyet niyetini güçlendiren önemli bir faktör olduğu belirlenmiştir. Böylece bu çalışma ilgili alanyazında var olan bulguları Türkiye'den bir örneklemde elde edilen sonuçlarla desteklemiştir.

Araştırmanın dördüncü hipotezi kendini önemseme ile niyet arasında bir ilişki öngörmektedir. Bulgular da kendini önemseme değişkeninin şikâyet etme niyetini etkilediğini $(\beta=0,60 ; t=6,77)$ göstermektedir. Bir başka ifade ile kendini önemseyen cevaplayıcıların şikâyet etme niyetlerinin de güçlü olduğu söylenebilir. Böylece araştırma- nın dördüncü hipotezi de bulgularla destek bulabilmiştir. İlgili alanyazına bakıldığında bu ilişkiyi doğrudan test eden çalışma sayısının çok az olduğu görülmektedir. Bu çalışmalardan biri olan Kim ve Chen'in (2010) araştırmasına göre kendini önemseme ile şikâyeti dillendirme davranışı arasında anlamlı bir ilişki tespit edilememiştir. İki çalı̧̧mada bağımsız değişken (kendini önemseme) aynı iken bağımlı değişkenler (şikâyet etme niyeti ve şikâyet etme davranışı) farklıdır. PDK niyeti davranışın temel belirleyicisi olarak görse de niyet ve davranış aynı anlama gelen kavramlar değildir. Nitekim iki çalışmada niyet ve davranışa ilişkin ölçümler de farklıdır. Söz gelimi Kim ve Chen (2010) şikâyeti dillendirme davranışını garsona, yönetici ya da restoran sahibine doğrudan şikâyet şeklinde ölçmüştür. İki çalışmada birbiri ile çelişen bulgular elde edilmiş olmasının sebebi ölçümlerdeki bu farklılık olabilir. Şu halde ilgili alanyazında kendini önemsemenin şikâyeti dillendirme davranışı üzerinde etkisi gösterilememişken (Kim ve Chen 2010), bu çalışma ile şikâyet etme niyeti üzerindeki etkisi saptanmış olmaktadır. Diğer taraftan Wei vd. (2012), benzer bir kavram olan benlik kurgusunu şikâyet davranışı (dillendirme) ile ilişkilendirmiş ve benlik kurgusu yüksek bireylerin şikâyetlerini dillendirme eğilimlerinin de yüksek olacağını saptamıştır. Benlik kurgusu yüksek kişilerin aynı zamanda kendilerini önemseyen kişiler olabileceği düşünüldüğünde bu çalışmanın bulguları ile Wei vd. (2012) tarafından elde edilen bulguların örtüştüğü söylenebilir.

Tablo 6'daki bulgular enformasyon düzeyinin şikâyet etme niyetini $(\beta=0,66 ; t=9,96)$ etkilediğini işaret etmektedir. Tüketici olarak haklarını bilen ve restoranlarda nereye, nasıl şikâyet edeceği konusunda enformasyon sahibi olanların şikâyet etme niyetlerinin de güçlü olduğu söylenebilir. Bulgular, araştırmanın beşinci hipotezini de desteklemektedir. Benzer şekilde, bir İspanyol şehrinde yaşayan 388 kişi ile yaptıkları araştırma sonucu Velazquez vd. de (2010) sahip olunan enformasyon düzeyinin şikâyet etme niyetini etkilediğini saptamıştır. Ancak yazarlar, diğer değiş̧enler arasında (tutum, durumun önemi, şikâyetin başarı ile sonuçlanma olasılığı, memnuniyetsizlik düzeyi) şikâyet etme niyeti üzerindeki etkisi en zayıf değişkenin enformasyon düzeyi olduğunu da belirtmektedir. Bu çalışmada ise standartlaştırılmış yol katsayılarına 
göre enformasyon düzeyi en güçlü ya da en zayıf etkiye sahip değişken olarak nitelenemese de etkinin oldukça güçlü olabileceği söylenebilir. Bu iki çalışma arasındaki farkın kaynaklarından biri enformasyon düzeyi ile birlikte ölçülen diğer değişkenlerin farklı olması olabilir. Enformasyon düzeyi dışında iki çalışma arasındaki tek ortak değişkenin tutum olduğu görülmektedir. Standartlaştırılmış yol katsayılarına bakıldığında aslında her iki çalışmada da tutum en etkili değişken olarak belirlenmiştir. Velazquez vd. (2010) durumun önemi ile şikâyet etme niyeti arasında anlamlı bir ilişki belirleyememişken sırası ile şikâyetin başarı ile sonuçlanma olasılığı ve memnuniyetsizlik düzeyinin niyetin belirleyicileri olduğunu tespit etmişlerdir. Bu çalışmada ise enformasyon düzeyi, tutum ve algılanan davranışsal kontrolden sonra standartlaştırılmış yol katsayısı en yüksek üçüncü değişken konumundadır. İki çalışmanın bulguları birlikte düşünüldüğünde enformasyon düzeyi açısından varılabilecek önemli bir sonuç, diğer değişkenlerin varlığına ve türüne göre bu değişkenin şikâyet etme niyeti üzerindeki etkisinin farklılık gösterebileceği ve göreli olarak düşük olabileceğidir. Ancak bu konu ile ilgili vurgulanması gereken nihai husus bu çalışma ile enformasyon düzeyinin şikâyet etme niyetini açıklarken dikkate alınması gereken önemli bir değişken olduğunun ortaya konmuş olmasidir.

\section{SONUÇ}

$\mathrm{Bu}$ araştırma ile bireysel ve davranışsal faktörlerin müşterilerin restoranlarda şikâyet etme niyetlerine etkisinin incelenmesi amaçlanmıştır. Davranışsal faktörler olarak PDK'nın temel değişkenleri (tutum, öznel normlar ve algılanan davranışsal kontrol); bireysel faktörler olarak da enformasyon düzeyi ve kendini önemseme inceleme kapsamına alınmıştır. Bu bağlamda geliştirilen beş hipotezin tamamı araştırma bulgularından destek bulabilmiştir.

$\mathrm{Bu}$ araştırma ile elde edilen bulgular şikâyete ilişkin tutumun, algılanan davranışsal kontrolün ve öznel normların restoranlarda müşterilerin şikâyet etmeye ilişkin niyetlerini belirleyen önemli faktörler olduğuna işaret etmektedir. Bu bulgular ışığında restoran işletmeleri bağlamında müşteri şikâyet davranışlarının anlaşılması için PDK'nın yararlı olabileceği söylenebilir. Diğer taraftan araştırma bulguları PDK değişkenlerine ek olarak restoranlarda müşterilerin şikâyet etme niyetlerinin enformasyon düzeyi ve kendini önemseme değişkenleri ile de açıklanabileceğine işaret etmektedir. Bir anlamda bu çalışma PDK'nın restoranlarda müşteri şikâyetlerinin açılklanmasında kullanılması sırasında enformasyon düzeyi ve kendini önemseme şeklinde iki değişkenle genişletilebileceğine de işaret etmektedir.

Bu çalışmanın bulguları restoran yöneticilerinin müşteri şikâyet davranışlarını anlamasına da yardımcı olabilir ve şikâyet yönetimi konusundaki uygulamalarını iyileştirmeleri için bir referans çerçevesi sağlayabilir. Aslında PDK kapsamındaki iki önemli değişken olan tutum ve öznel normlar ile bu araştırmayla modele ilave edilen kendini önemseme restoran yöneticilerinin doğrudan etkileyebilecekleri faktörler olmayabilir. Ancak, restoran yöneticileri müşterilerin kendi şikâyet davranışları üzerindeki kontrol algılamalarını ve enformasyon düzeylerini geliştirmelerine yardımcı olabilirler. Restoranlarında şikâyetin nasıl yapılacağına ilişkin güvenilir bir sistem geliştirmeleri ve çalışanlarına şikâyetleri dinleme ve çözüm önerme konusunda eğitim vermeleri bu konuda yapilabileceklerin başında gelmektedir. Müşteriler şikâyete ilişkin prosedürlerin güvenilir olduğuna inanırsa ve çalışanlarla sorunsuz bir iletişim kurabilirlerse şikâyet davranışlarına ilişkin algılanan kontrol düzeyleri de yükselecektir. Bununla birlikte şikâyetlerin yapılacağı kişi ya da merciinin müşteriler tarafından bilinir ve kolay ulaşılabilir olması, şikâyetlerin elektronik ortamlar üzerinden de iletilebilmesi gibi uygulamalar müşterilerin enformasyon düzeyini arttırmakla birlikte şikâyet etmenin kolaylığına ilişkin algılamalarını da olumlu yönde etkileyecektir. İşletmeler müşterilerinden herhangi bir hata karşısında şikâyetçi olmaları için aktif olarak talepte de bulunabilir. Bu da müşterilerin şikâyet etme eğilimlerini güçlendirecektir. Böylece restoran yönetimi müşteri memnuniyetsizliğine yol açan hatalara ilişkin geri bildirim alma olanağını bulacaktır. Ancak buradaki kritik nokta restoran yöneticilerinin şikâyetleri sadece olumsuz birer geri bildirim olarak görmemeleri, aksine hatalarını düzeltmek için bir fırsat olarak kabul etmeleri gerektiğidir.

\section{Kısıtlar ve İleriki Çalışmalar için Öneriler}

Bu araştırmada, kolayda örnekleme yöntemi kullanılmış ve tek bir şehrin işlek bir caddesinde sınırlı 
sayıda katılımcıya ulaşılabilmiştir. Ayrıca örneklemde yüksek eğitimliler daha büyük bir oranda temsil edilmektedir. Bu sebeplerle bu çalışma ile elde edilen bulguların genellenmesi doğru olmayacaktır. Ancak ileriki araştırmalarda bu çalışmada kullanılan ölçeklerden de yararlanılarak farklı şehirlerde ve daha büyük örneklemler üzerinde restoran müşterilerinin şikâyet davranışı ile ilgili modeller sınanabilir. Ayrica bu modeller ilgili alanyazında da yer alan başkaca değişkenlerle genişletilebilir. Bu çalışmada şikâyete ilişkin niyet, şikâyet davranışının göstergesi olarak kabul edilmiştir ve katılımcıların gerçek şikâyet davranışları gözlemlenmemiştir. Bu nedenle gözlemlenen davranış bir değişken olarak modelde yer almamıştır. $\mathrm{Bu}$ da niyet ile gözlenen davranış arasındaki ilişkinin testini olanaksız kılmıştır. Diğer taraftan, bazı durumsal faktörler (hatanın şiddeti, yemeğin önemi ve harcama tutarı gibi) niyet ile davranış arasındaki ilişkide aracılık rolü oynayabilir. Ancak bu tür ilişkilerin analizinde farklı bir araştırma desenine gerek duyulmaktadır. Araştırmacılar durumsal faktörlerin şikâyet davranışına etkisini incelerken daha çok senaryo yöntemini tercih etmektedir. İleriki araştırmalarda da şikâyete ilişkin niyet ve şikâyet davranışı arasındaki ilişkiyi ve bu ilişkide aracılık rolü oynayan değişkenleri incelemek üzere senaryo yönteminden yararlanılabilir. Bu çalışmada şikâyet etme niyetini etkileyen bir değişken olarak analizlere dahil edilmese de sosyo-demografik değişkenler, ilgili alanyazında şikâyet davranışı ile ilişkilendirilmektedir. Ancak önceki araştırmaların bu konuyla ilgili bulguları tutarlılık göstermemektedir. Bu nedenle ileriki çalışmalarda sosyo-demografik değişkenlerin şikâyet etme niyetine etkisi üzerine odaklanılabilir ve ilgili alanyazındaki karmaşıklığı giderecek bulgular elde etmek olanak11 olabilir. Son olarak ileriki çalışmalarda restoran yöneticilerinin müşteri şikâyetlerini yönetmeye ilişkin algıları da ölçülebilir. Böylece madalyonun diğer tarafında yer alan aktörlerin de restoranda müşteri şikâyet yönetimine ilişkin tutumları hakkındaki bulgulara ulaşılabilecektir.

$\mathrm{Bu}$ çalışma restoranlar bağlamında müşteri şikâyet davranışlarını anlamada yabancı alanyazında az sayıda çalışmada ölçülmüş olan, ulusal yazında ise henüz kullanılmamış olan değişkenler (tutum, algılanan davranışsal kontrol, öznel normlar, kendini önemseme ve enformasyon düzeyi) üzerine odaklanmıştır. Bu değişkenler arasında tutum diğerlerine göre daha fazla çalışmada kendisine yer bulabilse de ne ulusal ne de yabancı yazında bu çalışmada ele alınan değişkenlerin tamamı birlikte incelenmiş̧tir. Bu nedenle bu çalışma restoranlarda müşteri şikâyet davranışının anlaşılmasına PDK değişkenlerine ek olarak kendini önemseme ve enformasyon düzeyi değişkenlerini de ilave ederek ilgili alanyazına önemli bir katkı sunmaktadır.

\section{KAYNAKÇA}

Anderson, J. C. ve Gerbing, D. W. (1988). Structural Equation Modelling in Practice: A Review and Recommended Two-Step Approach, Psychological Bulletin, 103 (3): 411-423.

Ajzen, I. (1991). The Theory of Planned Behavior, Organizational Behavior and Human Decision Process, 50 (2): 179-211.

Ajzen I. ve Fishbein, M. (1970). Attitude-behavior Relations: A Theoretical Analysis and Review of Empirical Research, Psychological Bulletin, 84 (5): 888-918.

Antun, J. M., Frash, R. E., Costen, W. ve Runyan, R. (2010). Accurately Assessing Expectations Most Important to Restaurant Patrons: The Creation of the DineEx Scale, Journal of Foodservice Business Research, 13: 360-379.

Bagozzi, R. P., Wong, N., Abe, S. ve Bergami, M. (2000). Cultural and Situational Contingencies and the Theory of Reasoned Action: Application to Fast Food Restaurant Consumption, Journal of Consumer Psychology, 9 (2): 97-106.

Bentler, P. M. ve Chau, C. P. (1987). Practical Issues in Structural Modelling, Sociological Methods E Research, 16 (1): 78-117.

Chang, J., Khan, M. A. ve Tsai, C. T. (2012). Dining Occasions, Service Failures and Customer Complaint Behaviors: An Empirical Assessment, International Journal of Tourism Research, 14: 601-615.

Cheng, S. ve Lam, T. (2008). The Role of the Customer-Seller Relationship in the Intention of the Customer to Complain: A Study of Chinese Restaurateurs, International Journal of Hospitality Management, 27: 552-562.

Cheng, S., Lam, T. ve Hsu, C. H. C. (2005). Testing the Sufficiency of the Theory of Planned Behavior: A Case of Customer Dissatisfaction Responses in Restaurants, International Journal of Hospitality Management, 24: 475-492.

Chua, L. B., Othman, M. ve Abkarim, M. S. (2010). Servicescape Failure and Recovery Strategy in the Food Service Industry: The Effect on Customer Repatronization, Journal of Quality Assurance in Hospitality \& Tourism, 11: 179-198.

Çalışkan, O. (2013). Restoran İşletmelerinde Hizmet Hataları, Hizmet Telafi Stratejileri ve Müşteri Memnuniyeti İlişkisi, Seyahat ve Otel Işletmeciliği Dergisi (SOID), 10 (3): 65-83.

Day, R. L. ve Landon, E. L. (1977). Towards a Theory of Consumer Complaining Behavior, İçinde: Woodside, A. G., Sheth, J. N., Bennett, P. D. (Editörler), Consumer and Industrial Buying Behavior, (ss. 425- 437). New York: NorthHolland Publishing Company. 
DeFranco, A., Wortman, J., Lam, T. ve Countryman, C. (2005). A Cross-cultural Comparison of Customer Complain Behavior in Restaurants in Hotels, Asia Pasific Journal of Tourism Research, 10 (2): 173-190.

Ekiz, E. H. (2009). Factors Influencing Organizational Responses to Guest Complaints: Cases of Hong Kong and Northern Cyprus, Journal of Hospitality Marketing \& Management, 18 (6): 539-573.

Emir, O. (2011). Customer Complaints and Complaint Behaviors in Turkish Hotel Restaurants: An Application in Lara and Kundu Areas of Antalya, African Journal of Business Management, 5 (11): 4239-4253.

Fornell, C. ve Larcker, D. F. (1981). Evaluating Structural Equation Models with Unobservable Variables and Measurement Error, Journal of Marketing Research, 18 (1): 39-50.

Gursoy, D., McCleary, K. W. ve Lepsito, L. R. (2003). Segmenting Dissatisfied Restaurant Customers Based on Their Complaining Response Styles, Journal of Foodservice Business Research, 6 (1): 25-43.

Hansen, K. V., Jensen, Q. ve Gustafsson, I. (2005). The Meal Experience of A La Carte Restaurant Customers, Scandinavian Journal of Hospitality and Tourism, 5 (2): 135-151.

Heung, V. C. S. ve Lam, T., (2003). Customer Complaint Behavior towards Hotel Restaurant Services, International Journal of Contemporary Hospitality Management, 15 (5): 283-289.

Hirschman, A. O. (1970). Exit, Voice and Loyalty: Responses to Declaim in Firms, Organizations, and States. Cambridge: Harvard University Press.

Jayaram, J., Kannan, V. R. ve Tan, K. C. (2004). Influence of Initiators on Supply Chain Value Creation, International Journal of Production Research, 42 (20): 4377-4399.

Johns, N. ve Kivela, J. (2001). Perceptions of the First Time Restaurant Customer, Food Service Technology, 1: 5-11.

Jones, D. L., McClearly, K. W. ve Lawrence, R. L. (2002). Consumer Complaint Behavior Manifestation for Table Service Restaurants: Identifying Socio-demographic Characteristics, Personality, and Behavioral Factors, Journal of Hospitality \& Tourism Research, 26 (2): 105-123.

Karatepe, O. M. (2006). Customer Complaints and Organizational Responses: The Effects of Complainants' Perceptions of Justice on Satisfaction and Loyalty, International Journal of Hospitality Management, 25: 69-90.

Kim, J. H. ve Lynn, J. (2007). Classification of Asian Complainers in Restaurant Services, Asia Pacific Journal of Tourism Research, 12 (4): 366-375.

Kim, J. H. ve Chen, J. S. (2010). The Effects of Situational and Personal Characteristic on Consumer Complaint Behavior in Restaurant Services, Journal of Travel \& Tourism Marketing, 27: 96-112.

Kim, M. G., Wang, C. ve M, A. S. (2010). The Relationship between Consumer Complaining Behavior and Service Recovery, International Journal of Contemporary Hospitality Management, 22 (7): 975-991.

Kim, J. ve Boo, S. (2011). Influencing Factors on Customers' Intention to Complain in a Franchise Restaurant, Journal of Hospitality Marketing \& Management, 20: 217-237.
Kivela, J., Inbakaran, R. ve Reece, J. (2000). Consumer Research in the Restaurant Environment. Part 3: Analysis, Findings and Conclusions, International Journal of Contemporary Hospitality Management, 12 (1): 13-31.

Kitapçı, O. (2008). Restoran Hizmetlerinde Müşteri Şikâyet Davranışları: Sivas İlinde Bir Uygulama, Erciyes Üniversitesi İkisadi ve İdari Bilimler Fakültesi Dergisi, 31: 111-120.

Lam, T. ve Tang, V. (2003). Recognizing Customer Complaint Behavior: The Case of Hong Kong Hotel Restaurants, Journal of Travel \& Tourism Marketing, 14 (1): 69-86.

Leong, K. L. ve Kim, W. G. (2002). Service Recovery Efforts in Fast Food Restaurants to Enhance Repeat Patronage, Journal of Travel \& Tourism Marketing, 2/3 (12): 65-93.

Lodorfos, G. N. ve Dennis, J. (2008). Consumers' Intent in the Organic Food Market, Journal of Food Products Marketing, (14) 2: 17-38.

Lundberg, C. (2011). Critical Service Encounters in Hotel Restaurants: The Personnel's Perspective, Scandinavian Journal of Hospitality and Tourism, 11 (1): 1-19.

Mattila, A. S. ve Ro, H. (2008). Discrete Negative Emotions and Customer Dissatisfaction Response in a Casual Restaurant Setting, Journal of Hospitality \& Tourism Research, 32 (1): 89-107.

McQuilken, L. ve Robertson, N. (2011). The Influence of Guarantees, Active Request to Voice and Failure Severity on Customer Complaint Behavior, International Journal of Hospitality Management, 30: 953-962.

Murphy, K. R. ve Davidshofer, C. O. (1988). Psychological Testing: Principles and Applications. Englewood Cliffs, NJ: Prentice Hall.

O'Fallon, M., Gursoy, D. ve Swanger, N. (2007). To Buy or Not to Buy: Impact of Labeling on Purchasing Intentions of Genetically Modified Foods, International Journal of Hospitality Management, 26 (1): 117-130.

Ok, C., Back, K. J. ve Shanklin, C. W. (2006). Service Recovery Paradox: Implications from an Experimental Study in a Restaurant Setting, Journal of Hospitality \& Leisure Marketing, 3 (14): 17-31.

Rogers, J. C., Ross, S. C. ve William, T. G. (1992). Personal Values and Purchase Dissatisfaction Response, Journal of Consumer Satisfaction, Dissatisfaction and Complaining Behavior, 5 (1): 81-92.

Silber, I., Israeli, A., Bustin, A. ve Zvi, O.B. (2009). Recovery Strategies for Service Failures: The Case of Restaurants, Journal of Hospitality Marketing \& Management, 18: 730-740.

Singh, J. (1988). Consumer Complaint Intentions and Behavior: Definitional and Taxonomical Issues, Journal of Marketing, 52 (Ocak): 93-107.

$\mathrm{Su}, \mathrm{W}$. ve Bowen, J. T. (2001). Restaurant Customer Complaints Behavior, Journal of Restaurant \& Foodservice Marketing, 4 (2): 35-65.

Sujithamrak, S. ve Lam, T. (2005). Relationship between Customer Complaint Behavior and Demographic Characteristics: A Study of Hotel Restaurants' Patrons, Asia Pacific Journal of Tourism Research, 10 (3): 290-307. 
Susskind, A. M. (2005). A Content Analysis of Consumer Complaints, Remedies, and Repatronage Intentions Regarding Dissatisfying Service Experiences, Journal of Hospitality $\mathcal{E}$ Tourism Research, 29 (2): 150-169.

Susskind, A. M. ve Viccari, A. (2011). A Look at the Relationship between Service Failure, Guest Satisfaction, and RepeatPatronage Intention of Casual Dining Guests, Cornell Hospitality Quarterly, 4 (52): 438-444.

Şencan, H. (2005). Sosyal ve Davranışsal Ölçümlerde Güvenirlilik ve Geçerlilik. Ankara: Seçkin Yayıncılık.

Velazquez, B. M., Contri, G. B., Saura, I. G. ve Blasco, M. F. (2006). Antecedents to Complaint Behavior in the Context of Restaurant Goers, International Review of Retail, Distribution and Consumer Research, 16 (5): 493-517.

Velazquez, B. M., Blasco, M. F., Saura, I. G. ve Contri, G. B. (2010). Causes for Complaining Behavior Intentions: The Moderator Effect of Previous Customer Experience of the Restaurant, Journal of Service Marketing, 24 (7): 532-545.
Wei, W., Miao, L. Cai, L. ve Adler, H. (2012). The Influence of Self-Construal and Co-Consumption Others on Consumer Complaining Behavior, International Journal of Hospitality Management, 31: 764-771.

Weiss, R., Feinstein, A.H. ve Dalbor, M. (2004). Customer Satisfaction of Theme Restaurant Attributes and Their Influence on Return Intent, Journal of Foodservice Business Research, 7 (1): 23-41.

Wildes, J. W. ve Seo, W. (2001). Customers Vote with Their Forks: Consumer Complaining Behavior in the Restaurant Industry, International Journal of Hospitality \& Tourism Administration, 2 (2): 21-33.

Wu, C. H. ve Liang, R. (2009). Effects of Experiential Value on Customer Satisfaction with Service Encounters in Luxury-hotel Restaurants, International Journal of Hospitality Management. 28: 586-593. 